JEFFREY D. SACHS

Harvard University

\title{
Real Wages and Unemployment in the OECD Countries
}

An active Debate is now under way in the United States, Europe, and Japan about the scope for expansionary macroeconomic policies in the near term. Although unemployment is at postwar historical highs in Europe and the United States and inflation has receded rapidly in the major economies of the Organization for Economic Cooperation and Development, there is remarkable reticence in advocating expansionary policies among the governments of OECD countries. One school of thought holds that much of the unemployment problem in Europe, and to a lesser extent in the United States and Japan, results from real wages at inappropriate levels and thus the problem cannot be ameliorated by adjusting demand-management policies. The West German Minister of Economics strongly enunciated this view. ${ }^{1}$

Nevertheless, our economies are still carrying the burden of an excessive real wage level from the seventies. A considerable part of current unemployment is due to the fact that labour has now become too expensive. ... However, correcting false distribution relations needs time. A start has been made in most of the major industrial countries. The course must be held over the medium term if a growth process which does not bring with it a danger of inflation is to be set in motion and sustained.

Because this view has gained widespread currency, and because I took

Much of the work in this paper is based on a continuing project with Michael Bruno of Hebrew University, Jerusalem. This paper has benefited from our joint work, although the views expressed here are my own. Financial support from the National Science Foundation is gratefully acknowledged.

1. See Otto Lambsdorff, speech entitled "The Problems of Internationally Coordinated Change in the Industrial Countries' Economic Policy, ' unpublished paper, February 1983, available from the author upon request. 
this position under different circumstances in my 1979 BPEA paper, it is opportune to reexamine the arguments in light of recent circumstances. ${ }^{2}$

The real wage issue seems to invite extreme positions. In some models real wages are of no significance for macroeconomic outcomes, while in others they are of decisive importance. Not surprisingly, a middle position appears to be firmly supported by the data. High real wage levels are an important, though by no means exclusive, factor explaining the high levels of unemployment in OECD countries during much of the past decade. Real wages do not explain the sharp jump in unemployment since 1980 in most countries; that jump is clearly tied to monetary contraction rather than to supply factors. Real wages do, however, help explain the secular rise in unemployment since 1973. Furthermore, while high real wages complicate demand-management policies, they do not preclude them. Recall that Keynes saw demand expansion as a solution to high real wages; in some circumstances high demand can allow prices to rise relative to rigid nominal wages.

One of the themes of my 1979 BPEA article was the difference in structure between U.S. and European wage-price behavior. That difference continues to pervade almost every equation described in this paper. Thus for the United States an index of the cyclically corrected labor share-termed a real wage gap-is not a good indicator of aggregate supply conditions, but it is a useful measure in Europe and Japan. Outside the United States, tight labor markets often lead to significant increases in real wages. It is partly the expectation that real wages will increase that forestalls a demand expansion in those countries, particularly Germany.

This discussion of the current real wage problem is divided into three parts. The first section provides a summary of wage and profit developments in recent years, with a focus on the post-1979 period, and constructs a simple wage-gap variable. The second section confirms that the wage-gap variable is a useful measure of aggregate supply conditions

2. Jeffrey D. Sachs, "Wages, Profits and Macroeconomic Adjustment: A Comparative Study," BPEA, 2:1979, pp. 269-319. Michael Bruno and I discuss the wage issue in a macroeconomic context in several papers, including "Supply versus Demand Approaches to the Problem of Stagflation," in Herbert Giersch, ed., Macroeconomic Policies for Growth and Stability: A European Perspective (Kiel: Institut für Weltwirtschaft, 1981), pp. 15-60; and Sachs and Bruno, "Input Price Shocks and the Slowdown in Economic Growth: The Case of U.K. Manufacturing," Review of Economic Studies, vol. 49 (5), no. 159 (1982), pp. 679-705. 
outside the United States. The wage gap helps to explain three central macroeconomic developments: the time path of unemployment in OECD countries, the shifts in the Phillips curve in several countries since the early 1970s, and the decline in profitability in the same period. The third section takes up the most delicate issue: the implications of high realwage levels for demand management, both at the current time and more generally. The last section addresses policy choices in the near term. Some technical problems related to the wage-gap measure are discussed in an appendix.

\section{Recent Wage Developments in the Major OECD Economies}

Since 1979, high-unemployment, low-productivity growth, and deterioration of the terms of trade in the OECD countries have substantially depressed real wage growth in most of these economies. Table 1 shows the growth rates of real hourly compensation in manufacturing (with the consumer price index as the price deflator) for six of the seven large OECD economies from 1960 to 1982. Data limitations for Italy preclude its treatment here. In all these economies except the United Kingdom real hourly compensation has slowed sharply since 1979, on the order of 2.5 percentage points a year. Compensation includes social security contributions and provides a comprehensive measure of labor costs but does not represent take-home pay. Real take-home pay per hour worked has decelerated even more dramatically in recent years. In the United Kingdom the breakdown of incomes policies under the Labour government after 1978 and new government wage concessions during 1979-80 kept growth of real wages high during 1979-81.

It continues to appear that only extreme duress in the labor markets can bring about real wage deceleration in the European economies. After the first oil shock in 1973, real wage increases hardly slowed in Europe until after 1975 and then did so only in an environment of extremely high unemployment. After 1980, economic weakness again led to a substantial deceleration of real wages.

Despite the poor growth in real wages in recent years, profitability has not improved in the major economies. In the United Kingdom, the United States, France, and Germany the share of labor income in manufacturing value added, $S_{L}$, was higher in 1981 than 1978 , and this is 
Table 1. Annual Percentage Changes in Real Hourly Compensation for Manufacturing, Selected Periods, 1960-82 ${ }^{\text {a }}$

Percent per year

\begin{tabular}{lccrrrr}
\hline \multicolumn{1}{c}{ Country } & $1960-73$ & $1973-79$ & $1979-81$ & 1980 & 1981 & $1982^{\mathrm{b}}$ \\
\hline Canada & 2.8 & 2.5 & -0.6 & -1.0 & -1.1 & 0.8 \\
France & 5.3 & 4.3 & 1.8 & 2.8 & 0.8 & 3.0 \\
Germany & 6.4 & 5.3 & 2.2 & 2.9 & 1.5 & -0.3 \\
Japan & 8.2 & 2.3 & 0.5 & -1.5 & 2.5 & 2.1 \\
United Kingdom & 3.7 & 3.7 & 3.8 & 4.9 & 2.7 & 2.4 \\
United States & 1.8 & 0.9 & -0.9 & -1.6 & -0.1 & 0.2 \\
\hline
\end{tabular}

Sources: Compensation is from U.S. Department of Labor, Bureau of Labor Statistics, Office of Productivity and Technology, "Underlying Data for Indexes of Output per Hour, Hourly Compensation, and Unit Labor Costs in Manufacturing, Eleven Countries, 1950-81" (BLS, 1982); the consumer price index is from International Monetary Fund, International Financial Statistics, various issues; and earnings for 1982 are from Organization for Economic Cooperation and Development, Main Economic Indicators, various issues.

a. Real hourly compensation is defined as nominal hourly compensation deflated by the consumer price index.

b. Hourly earnings instead of compensation. The 1982 data are preliminary.

also true after adjusting $S_{L}$ for cyclical productivity shifts to produce a "full-employment" labor share, $S_{L}^{f}$. (The method of adjustment is described below.) Both $S_{L}$ and $S_{L}^{f}$ are shown in table 2. The table shows that, in the four countries with 1981 data, the levels of $S_{L}$ and $S_{L}^{f}$ are far above their 1969 levels.

These shifts in labor's share are closely mirrored by changes in the pretax rate of return to capital in the manufacturing sector. In the United States the profit rate in manufacturing fell from 17.5 percent in 1978 to 12.4 percent in 1981, according to OECD definition. ${ }^{3}$ In Germany there was a decline from 14.6 in 1978 to 13.0 in 1980; and in the United Kingdom from 7.8 percent in 1978 to 4.1 percent in 1981. (Recent data are not yet available for the other OECD economies.) As discussed in my 1979 BPEA paper, the 1978 levels were already quite depressed.

The $S_{L}^{f}$ measure is calculated by adjusting actual $S_{L}$ for cyclical movements in productivity. This $S_{L}$ can be written as $\left(W / P_{V}\right)(V / L)$, where $W, V$, and $L$ are hourly compensation, value-added output, and total man-hours, respectively; and $P_{V}$ is the value-added deflator. The variables represent the manufacturing sector only, for lack of data from other sectors. The $S_{L}^{f}$ measure is constructed by replacing $(V / L)$ by $(V / L)^{f}$, where the latter is average labor productivity when labor is fully employed.

3. The pretax profit rate is the gross operating surplus (profit plus adjustment for capital consumption plus income of self-employed persons) divided by the replacement cost of the gross capital stock. 
Table 2. Share of Labor in Manufacturing Value Added, Selected Years, 1969-81 ${ }^{a}$ Percent

\begin{tabular}{llllllllll}
\hline & \multicolumn{4}{c}{ Actual share } & & \multicolumn{3}{c}{ Normalized share } \\
\cline { 2 - 4 } \multicolumn{1}{c}{ Country } & 1969 & 1973 & 1978 & 1981 & & 1969 & 1973 & 1978 & 1981 \\
\hline Canada & 68.5 & 65.8 & 67.1 & n.a. & & 68.1 & 65.8 & 67.1 & n.a. \\
France & 42.0 & 44.8 & 45.6 & 47.4 & & 42.6 & 44.8 & 45.6 & 45.8 \\
Germany & 52.3 & 58.8 & 59.5 & 63.3 & & 54.2 & 58.8 & 59.7 & 61.3 \\
Japan & 40.3 & 44.5 & 50.2 & n.a. & & 41.0 & 44.5 & 49.4 & n.a. \\
United Kingdom & 70.0 & 71.4 & 74.0 & 82.8 & & 70.0 & 71.4 & 72.9 & 83.9 \\
United States & 69.1 & 71.6 & 71.6 & 75.6 & & 69.4 & 71.6 & 72.2 & 75.3 \\
\hline
\end{tabular}

Source: Author's calculations based on data from Bureau of Labor Statistics, "Underlying Data for Indexes of Output per Hour."

n.a. Not available.

a. Actual labor share is total labor cost divided by nominal value added in manufacturing. The normalized share is described in the text. Value added is gross product at market prices in manufacturing for all countries except Canada and the United Kingdom, in which it is valued at factor cost.

Because $\left(V / L^{f}\right)$ is not observed, it must be estimated, and preferably in a straightforward and theory-free manner, so as not to prejudge some of the subsequent analysis. For this reason, I make the simple assumptions that (1) actual productivity equaled full-employment productivity in 1960,1973 , and $1979 ;(2)(V / L)^{f}$ grew at a constant exponential rate during the 1960-73 and 1973-79 periods; and (3) the growth rate of $(V / L)^{f}$ during $1979-81$ is a simple average of the observed rate and the 1973-79 rate. ${ }^{4}$ As discussed below, these calculations may overstate $(V / L)^{f}$ in the recent recession; if they do, the normalized labor share could be larger than calculated. ${ }^{5}$

4. One must take some position on the role of cyclical versus trend factors in the sharp productivity slowdown in France and Germany after 1979. This is clearly hard to do as of early 1983. Suppose that in 1976 one tried to forecast the 1973-79 rate by the procedure described in the text (averaging the rates of 1960-73 and 1973-75). The result would have been prediction of a post-1973 slowdown (the 1960-73 rate minus the 1973-79 rate) of 1.9 percent in the United States (versus 1.7 actual); 0.3 percent in Germany (0.1 actual); 2.4 percent in the United Kingdom (2.7 actual); 0.7 percent in France (1.2 actual); 2.9 percent in Canada (2.6 actual); and 2.6 percent in Japan (3.2 actual). These estimates are thus fairly accurate, and would have proved far superior to a simple extension of the 1960-73 productivity trend to 1974 and 1975.

5. One of the points made below is that in the high-unemployment period of the $1970 \mathrm{~s}$, declining manufacturing employment involved the shutdown of least-efficient, laborintensive firms. Thus, fairly systematically across countries, sustained rises in unemployment actually raised measured productivity relative to trend, as low-efficiency firms were eliminated from the data. Since 1979 unemployment in Europe was well above 1973 levels, the observed productivity level in 1979 may be biased upward relative to $(V / L)^{f}$. This effect appears strongest in Germany and France, and weakest in Japan, where lifetime employment policies in manufacturing preclude large-scale, rapid closing of inefficient plants. 
Table 3. Shifts in Normalized Labor Share of Manufacturing Value Added, Selected Periods, 1973-81 ${ }^{\text {a }}$

Percentage points

\begin{tabular}{lcccc}
\hline $\begin{array}{c}\text { Period and } \\
\text { country }\end{array}$ & $\begin{array}{c}\text { Total } \\
\text { average } \\
\text { rise }\end{array}$ & $S_{L}\left(w-p_{C}\right)$ & $S_{L}\left(p_{C}-p_{v}\right)$ & $-S_{L}(v-\ell)^{f}$ \\
\hline 1973-78 & & & & \\
France & 0.1 & 2.1 & 0.4 & -2.3 \\
Germany & 0.2 & 3.4 & -0.1 & -3.1 \\
United Kingdom & 0.3 & 2.5 & -0.8 & -1.3 \\
United States & 0.1 & 1.1 & 0.2 & -1.1 \\
1978-81 & & & & \\
France & 0.0 & 1.0 & 0.8 & -1.8 \\
Germany & 0.5 & 1.8 & 1.3 & -2.5 \\
United Kingdom & 3.7 & 3.4 & 2.2 & -1.8 \\
United States & 1.0 & -0.9 & 3.1 & -1.1 \\
\hline
\end{tabular}

Source: Same as table 2. The method of calculation is shown in text equation 1.

a. Canada and Japan are omitted because comparable data are not available.

b. Components may not add to total because equation 1 is an approximation. As described in the text, labor share is indicated by $S_{L}$ and full employment, by $f$. The rates of change are denoted as follows: real manufacturing GNP, $\nu$; man-hours, $\ell$; consumer prices, $p_{c}$; manufacturing deflator, $p_{v}$; and hourly compensation, $w$.

It is useful to ask why $S_{L}^{f}$ is higher in 1981 than in 1978, given the low real wage growth during 1978-81. By the definition of labor share, one can write the percentage change in $S_{L}^{f}$ as equal to real wage growth minus trend productivity growth, minus the change in consumer prices relative to manufacturing value-added prices. In countries in which real wage growth has slowed, it has been more than matched by a combination of productivity slowdown and shifts in the terms of trade against manufacturing - that is, shifts in $P_{C}$ relative to $P_{V}$. Formally, one can write

$$
\Delta S_{L}^{f}=\left[S_{L}\left(w-p_{C}\right)+S_{L}\left(p_{C}-p_{V}\right)-S_{L}(v-\ell)^{f}\right],
$$

where $\Delta$ signifies annual changes in level and lowercase variables indicate annual rates of change of their uppercase counterparts. The $S_{L}\left(p_{C}-p_{V}\right)$ term captures changes from several sources: supply shocks, in which input prices change in real terms; changes in indirect tax rates; changes in exchange rates, which vary prices of nontraded goods relative to manufacturing tradables; and demand shifts away from or toward manufacturing.

Table 3, which provides an accounting of $\Delta S_{L}^{f}$ for 1973-78 and 1978- 
Table 4. The Wage Gap in Manufacturing, Selected Periods and Years, 1960-82a Percent

\begin{tabular}{lccrrrr}
\hline \multicolumn{1}{c}{ Country } & $1960-64$ & $1965-69$ & 1973 & 1978 & 1981 & 1982 \\
\hline Canada & -0.6 & 0.0 & -1.4 & 0.6 & n.a. & n.a. \\
France & -0.2 & 0.0 & -0.3 & 1.5 & 1.9 & 4.4 \\
Germany & -2.2 & 0.0 & 8.0 & 9.4 & 12.2 & 8.9 \\
Japan & 0.2 & 0.0 & 9.8 & 20.3 & n.a. & n.a. \\
United Kingdom & -2.8 & 0.0 & 3.1 & 5.3 & 19.3 & 19.0 \\
United States & 1.8 & 0.0 & 3.1 & 3.9 & 8.1 & 9.0 \\
\hline
\end{tabular}

Source: Same as table 2 .

n.a. Not available.

a. The wage gap, $W^{g}$, is defined as $\log S_{L}^{f}(t)-\log S_{L}(1965-69)=\log \left[\left(W / P_{V}\right) /(V / L)^{f}\right]-\log \left[\left(W / P_{V}\right) /(V / L)^{f}\right]_{1965-69}$, where $f$ is full employment and the variables are the same as those whose rates of change are shown in table 3 , note b. See text and the appendix for a more complete description.

81 , is based on equation 1 . The striking fact about the table is the important role played by $p_{C}-p_{V}$ in the manufacturing profit squeeze since 1978, a much larger role than was seen during 1973-78. Part of this shift reflects the second oil shock. The especially large values in the United States and the United Kingdom reflect the added effects of the sharp appreciation of exchange rates, which have narrowed margins in tradable goods. In the United Kingdom there was also an important increase in indirect taxes. To these factors one may add another: a more general shift in demand away from manufacturing to other domestic sectors, which makes the profit squeeze in manufacturing a sectoral rather than economy-wide phenomenon. Because of data limitations on wages and productivity in other sectors, I have not examined this last factor closely. Finally, table 3 shows that a slowdown in productivity growth after 1978, reflected in falling absolute values of $-S_{L}(v-\ell)^{f}$, also plays a significant role in accounting for $\Delta S_{L}^{L}$.

Table 4 presents estimates of a concept I call the wage-gap. I assume that the normalized labor share was at an appropriate level for full employment during 1965-69 and define the wage gap, $W^{g}$, in any year as the departure of the normalized share from that level, measured by log $S_{L}^{f}(t)-\log S_{L}^{f}(1965-69)$. The wage gap in several countries is shown in table 4 for various years; it is positive in all OECD countries in the table in recent years, indicating that the normalized labor share of value added in manufacturing has risen since 1965-69.

The $W^{g}$ measure is related to labor demand. Under three conditionsif the production function is Cobb-Douglas, with $V=\left(e^{\lambda t} L\right)^{\alpha} K^{(1-\alpha)}$; if 
firms are not demand constrained; and if they remain along the production frontier-profit-maximizing labor demand, $L^{D}$, can be given as ${ }^{6}$

$$
\log \left(L^{D} / L^{f}\right)=-[1 /(1-\alpha)] W^{g},
$$

that is, the percentage deviation of labor demand from full employment is a linear function of the constructed wage gap. Actual labor demand is not given by equation 2 because the three conditions do not generally obtain. Nonetheless, $W^{g}$ is a good predictor of labor demand in most OECD economies, as shown below. Note also that desired output supply, $V^{s}$, relative to potential output supply, $V^{f}$, can be written as

$$
\log \left(V^{s / V^{f}}\right)=-[\alpha /(1-\alpha)] W^{g} .
$$

Again, there is no presumption that $V^{S}$ closely tracks actual output, $V$.

The precise measures shown for $W^{g}$ in table 4 are subject to several possible biases. Some of the major measurement problems are taken up in the appendix. But $W^{g}$ does contain important information as discussed in the following.

\section{The Wage Gap as an Indicator of Aggregate Supply}

The wage-gap concept can be judged by its usefulness for determining aggregate supply conditions, and on this basis even the very simple measure estimated here does well. Three examples are analyzed. First, $W^{g}$ can track the pattern of unemployment in most OECD economies, particularly if additional demand-side variables are also utilized. Second, this variable can help to explain shifts in the Phillips curve in several economies. The idea here is that price changes are a function of aggregate demand, $V^{D}$, relative to aggregate supply, $V^{S}$; a rise in $W^{g}$ reduces $V^{S}$ and makes inflation intensify for a given level of aggregate demand. Third, $W^{g}$ helps to explain the decline in profitability in most of these economies even when cyclical variables are also added to the profit equations.

6. Up to a constant, the wage gap is defined as $\log \left[\left(W / P_{V}\right) /(V / L)^{f}\right]$, or $\log \left(W / P_{V}\right)-$ $\log (V / L)^{f}$. Assuming $\partial V / \partial L=W / P_{V}$, we see that $W / P_{V}$ is proportional to $V / L$. Thus, up to a constant, $W^{g}=\log (V / L)-\log (V / L)^{f}$, which upon substitution of the production technology yields equation 2 . 
In all these applications, $W^{g}$ is less powerful in the United States than in the other OECD economies, suggesting both that U.S. fluctuations have been largely demand-driven, and that U.S. supply conditions cannot be measured well by observed ratios of wages to productivity. But the results also point out the danger of generalizing U.S. econometric results. The widely recognized cyclical independence of real wages and unemployment in the United States simply does not hold as a general proposition for other economies.

Table 5 presents regressions for the six OECD countries. In the first regression unemployment is regressed on its own lagged value, a time trend for productivity growth, a trend shift after 1974, and the logarithm of the lagged product wage:

$$
U_{t}=\alpha_{0}+\alpha_{1} U_{t-1}+\alpha_{2} \text { time }+\alpha_{3} t_{l 975-81}+\alpha_{4} \log \left(W / P_{V}\right)_{t-1} .
$$

In the second regression the last two variables are replaced by the lagged wage gap:

$$
U_{t}=\alpha_{0}+\alpha_{1} U_{t-1}+\alpha_{2} \text { time }+\alpha_{3} W_{t-1}^{g} .
$$

The results show a strong positive relation between the real wage, or wage gap, and unemployment in four of the six OECD economies; the relation is weak and statistically insignificant in France and the United States. The unemployment rate for Japan is a notoriously sluggish indication of cyclical conditions. It is used here and in subsequent tables to include Japan in the analysis on a consistent basis with the other countries studied. According to the point estimates, each increase of 1.0 percentage point in the product wage relative to trend raises the unemployment rate in the long run by 0.5 percentage point in Canada, 0.04 point in France, 0.4 point in Germany, 0.04 point in Japan, and 1.1 points in the United Kingdom. There are several reasons, however, not to take such point estimates too seriously, the main one being that the equations do not truly identify an aggregate labor-demand schedule, as shown below.

The results for estimates of equations 4 and 5 are a bit surprising in light of a long history of papers in which the real wage is shown to be acyclical or even procyclical. Keynes wrote in the General Theory that a real wage squeeze was necessary to explain the supply response of 
Table 5. Regressions of Aggregate Unemployment on the Wage Gap, 1961-81 ${ }^{\text {a }}$

\begin{tabular}{|c|c|c|c|c|c|c|c|c|}
\hline \multirow[b]{3}{*}{ Country } & \multicolumn{6}{|c|}{ Independent variable } & & \\
\hline & \multirow{2}{*}{$\begin{array}{c}\text { Lagged } \\
\text { unem- } \\
\text { ploy- } \\
\text { ment } \\
\text { rate }\end{array}$} & \multirow[b]{2}{*}{$\begin{array}{l}\text { Time } \\
\text { trend }\end{array}$} & \multirow[b]{2}{*}{$\begin{array}{c}\text { Trend } \\
\text { shift }\end{array}$} & \multirow{2}{*}{$\begin{array}{c}\text { Log of } \\
\text { lagged } \\
\text { product } \\
\text { wage }\end{array}$} & \multirow{2}{*}{$\begin{array}{c}\text { Lagged } \\
\text { wage } \\
\text { gap }\end{array}$} & \multirow{2}{*}{$\begin{array}{c}\text { Log of } \\
\text { lagged } \\
\text { real } \\
\text { money } \\
\text { balance }\end{array}$} & \multicolumn{2}{|c|}{$\begin{array}{l}\text { Summary } \\
\text { statistic }\end{array}$} \\
\hline & & & & & & & $\overline{R^{2}}$ & $\begin{array}{c}\text { Durbin- } \\
H\end{array}$ \\
\hline \multirow[t]{3}{*}{ Canada $^{c}$} & $\begin{array}{c}0.63 \\
(3.55)\end{array}$ & $\begin{array}{c}-0.80 \\
(-1.97)\end{array}$ & $\begin{array}{c}0.59 \\
(1.81)\end{array}$ & $\begin{array}{l}18.05 \\
(2.09)\end{array}$ & $\cdots$ & & 0.78 & 2.55 \\
\hline & $\begin{array}{c}0.63 \\
(5.46)\end{array}$ & $\begin{array}{c}0.07 \\
(2.82)\end{array}$ & $\ldots$ & $\ldots$ & $\begin{array}{l}15.72 \\
(2.23)\end{array}$ & $\ldots$ & 0.85 & 0.45 \\
\hline & $\begin{array}{c}0.52 \\
(3.05)\end{array}$ & $\begin{array}{c}0.13 \\
(1.93)\end{array}$ & $\cdots$ & $\cdots$ & $\begin{array}{l}19.59 \\
(2.39)\end{array}$ & $\begin{array}{c}-1.09 \\
(-0.94)\end{array}$ & 0.84 & 1.34 \\
\hline \multirow[t]{3}{*}{ France } & $\begin{array}{c}0.56 \\
(2.88)\end{array}$ & $\begin{array}{c}-0.03 \\
(-0.19)\end{array}$ & $\begin{array}{c}0.24 \\
(2.50)\end{array}$ & $\begin{array}{c}1.92 \\
(0.69)\end{array}$ & $\cdots$ & $\cdots$ & 0.98 & 0.19 \\
\hline & $\begin{array}{c}0.92 \\
(8.24)\end{array}$ & $\begin{array}{c}0.06 \\
(2.05)\end{array}$ & $\cdots$ & $\cdots$ & $\begin{array}{c}4.45 \\
(1.51)\end{array}$ & $\ldots$ & 0.97 & -0.38 \\
\hline & $\begin{array}{c}0.42 \\
(1.87)\end{array}$ & $\begin{array}{c}0.30 \\
(3.01)\end{array}$ & $\cdots$ & $\cdots$ & $\begin{array}{l}8.07 \\
(2.70)\end{array}$ & $\begin{array}{c}-4.31 \\
(-2.49)\end{array}$ & 0.98 & n.a. \\
\hline \multirow[t]{3}{*}{ Germany } & $\begin{array}{c}0.51 \\
(3.11)\end{array}$ & $\begin{array}{c}-1.03 \\
(-2.88)\end{array}$ & $\begin{array}{c}0.11 \\
(0.95)\end{array}$ & $\begin{array}{l}18.24 \\
(3.16)\end{array}$ & $\ldots$ & $\cdots$ & 0.89 & 0.54 \\
\hline & $\begin{array}{c}0.55 \\
(4.44)\end{array}$ & $\begin{array}{c}-0.04 \\
(-0.92)\end{array}$ & $\cdots$ & $\cdots$ & $\begin{array}{l}18.37 \\
(3.53)\end{array}$ & $\cdots$ & 0.90 & 0.17 \\
\hline & $\begin{array}{c}0.41 \\
(4.10)\end{array}$ & $\begin{array}{c}0.41 \\
(3.36)\end{array}$ & $\cdots$ & $\cdots$ & $\begin{array}{l}17.57 \\
(4.55)\end{array}$ & $\begin{array}{c}-9.46 \\
(-3.86)\end{array}$ & 0.95 & -0.53 \\
\hline \multirow[t]{3}{*}{ Japan } & $\begin{array}{c}0.19 \\
(1.45)\end{array}$ & $\begin{array}{c}-0.36 \\
(-3.98)\end{array}$ & $\begin{array}{c}0.14 \\
(3.86)\end{array}$ & $\begin{array}{c}3.50 \\
(4.23)\end{array}$ & $\ldots$ & $\ldots$ & 0.93 & -1.05 \\
\hline & $\begin{array}{l}0.35 \\
(2.72)\end{array}$ & $\begin{array}{c}-0.01 \\
(-1.03)\end{array}$ & $\cdots$ & $\ldots$ & $\begin{array}{c}3.36 \\
(3.99)\end{array}$ & $\ldots$ & 0.94 & -1.30 \\
\hline & $\begin{array}{c}0.20 \\
(1.31)\end{array}$ & $\begin{array}{c}0.02 \\
(0.96)\end{array}$ & $\cdots$ & $\cdots$ & $\begin{array}{c}3.34 \\
(4.11)\end{array}$ & $\begin{array}{c}-0.31 \\
(-1.55)\end{array}$ & 0.94 & -1.17 \\
\hline \multirow[t]{3}{*}{$\begin{array}{l}\text { United } \\
\text { Kingdom }\end{array}$} & $\begin{array}{c}0.82 \\
(2.40)\end{array}$ & $\begin{array}{c}-0.95 \\
(-2.81)\end{array}$ & $\begin{array}{c}0.68 \\
(4.09)\end{array}$ & $\begin{array}{l}20.05 \\
(3.08)\end{array}$ & $\ldots$ & $\ldots$ & 0.92 & n.a. \\
\hline & $\begin{array}{l}1.13 \\
(5.48)\end{array}$ & $\begin{array}{c}-0.15 \\
(-2.01)\end{array}$ & $\ldots$ & $\cdots$ & $\begin{array}{l}23.61 \\
(4.20)\end{array}$ & $\ldots$ & 0.91 & 1.57 \\
\hline & $\begin{array}{c}0.85 \\
(4.33)\end{array}$ & $\begin{array}{c}-0.01 \\
(-0.17)\end{array}$ & $\cdots$ & $\cdots$ & $\begin{array}{l}14.66 \\
(2.58)\end{array}$ & $\begin{array}{c}-9.32 \\
(-2.84)\end{array}$ & 0.94 & 2.82 \\
\hline \multirow[t]{3}{*}{ United States } & $\begin{array}{c}0.68 \\
(3.68)\end{array}$ & $\begin{array}{c}-0.68 \\
(-1.41)\end{array}$ & $\begin{array}{c}0.18 \\
(0.99)\end{array}$ & $\begin{array}{l}22.10 \\
(1.51)\end{array}$ & $\ldots$ & $\ldots$ & 0.55 & 1.28 \\
\hline & $\begin{array}{c}0.62 \\
(3.43)\end{array}$ & $\begin{array}{c}0.04 \\
(1.04)\end{array}$ & $\ldots$ & $\ldots$ & $\begin{array}{l}10.67 \\
(1.07)\end{array}$ & $\ldots$ & 0.54 & 1.93 \\
\hline & $\begin{array}{c}0.32 \\
(1.50)\end{array}$ & $\begin{array}{c}0.38 \\
(2.41)\end{array}$ & $\cdots$ & $\cdots$ & $\begin{array}{l}-15.28 \\
(-1.03)\end{array}$ & $\begin{array}{l}-11.17 \\
(-2.20)\end{array}$ & 0.54 & 1.31 \\
\hline
\end{tabular}

Sources: Author's estimates of text equations 4, 5, and 6. Data are from sources cited in table 1, with the exception of the unemployment rate and the money stock, which are from OECD, Main Economic Indicators, and IMF, International Financial Statistics, respectively.

n.a. Not available.

a. The dependent variable is the aggregate unemployment rate. The product wage and the wage gap refer to the manufacturing sector. All lags are one-period lags. The numbers in parentheses are $t$-statistics.

b. M1 is used for all countries except the United States, where M2 is used.

c. Data are for $1961-80$. 
firms to a demand contraction; but Dunlop and Tarshis challenged him in the late 1930s on this point using U.S. data. ${ }^{7}$ And they have been supported by subsequent studies. Recent work by Geary and Kennan purports to show that real wages and employment are independent in other countries also, in contradiction to the findings here, but several technical aspects of that work are troubling and cast doubt on their conclusions. Grubb, Layard, and Symons have recently reached conclusions in unpublished work similar to those of table $5 .{ }^{8}$

There are two ways to reconcile the conclusions of this paper with the established literature. First, the United States is simply different, and the literature has mainly dealt with the United States. I show below that real wages in the Great Depression moved countercyclically in Europe and procyclically in the United States, so that the differences appear to be long-standing. Second, even in Europe it is doubtful that real wages move countercyclically in all business cycles and likely that the supply shocks of the 1970s have strengthened the links between $W^{8}$ and $U$ in recent years. Malinvaud convincingly argued in 1977 that different cycles may have different characteristics in this regard; the 1970s happened to be a period of adverse supply shocks that pushed firms onto their labor-demand schedules. ${ }^{9}$

7. These classic articles are John T. Dunlop, "The Movement of Real and Money Wages," Economic Journal, vol. 48 (September 1938), pp. 413-34; and Lorie Tarshis, "Changes in Real and Money Wages," Economic Journal, vol. 49 (March 1939), pp. $150-54$.

8. Patrick T. Geary and John Kennan, "The Employment-Real Wage Relationship: An International Study," Journal of Political Economy, vol. 90 (August 1982), pp. 85471; and D. Grubb, R. Layard, and J. Symons, "Wages, Unemployment and Incomes Policy," unpublished manuscript, London School of Economics, 1982.

The most important problem with the Geary-Kennan analysis is that the wage is measured relative to the wholesale price index (WPI), rather than to $P_{V}$. This procedure is treacherous in a period of supply shocks, which raise WPI relative to $P_{V}$. It appears that the real wage has decreased when measured as W/WPI, when in fact it has increased when measured as $W / P_{V}$. Grubb, Layard, and Symons show that when employment is regressed on W/WPI in an equation that also includes a real price of intermediate inputs (which Geary and Kennan exclude), the expected negative relation between the real wage and employment is found. The regressions of table 5 show directly that when $W / P_{V}$ rather than $W / W P I$ is the explanatory variable, the negative wage-employment link is established. Also, Geary and Kennan fail to allow for the productivity slowdown after 1973.

9. Edmond Malinvaud, Theory of Unemployment Reconsidered (John Wiley, 1977). 


\section{DEMAND AND SUPPLY}

Even if the wage gap rises with higher unemployment, one cannot say whether demand or supply factors are behind the rise. Since 1979, for example, demand (monetary) contraction has strengthened the dollar in the United States and raised both $W^{g}$ and unemployment. Supply factors in Europe and Japan were probably responsible for the sharp rise in $W^{g}$ throughout the early and mid-1970s. Thus the statement that wages are too high does not imply that supply rather than demand factors explain the increased unemployment, only that real wages must grow more slowly than trend productivity to restore full employment.

With cyclical disequilibrium, demand factors can raise unemployment directly without raising $W^{g}$. This has been the case since 1979 , with the strong monetary contractions in the major OECD economies. It is worth stressing just how contractionary monetary policies have been in recent years. Real money balances grew at 6.1 percent a year in Germany during 1975-78, then declined at 3.3 percent a year during 1978-81. In the United States they grew 0.7 percent annually during 1975-78 and declined 4.8 percent a year during $1978-81$. In the United Kingdom the growth rates for the two periods were 2.5 and -4.0 percent, respectively.

The evidence that the recent rise in unemployment is not induced by wage gaps is shown in the display below, which presents actual and forecast unemployment rates in 1982 based on the estimates of table 5. The first three columns of this display use the basic wage-gap equation 5. In Germany and the United States these equations fail to account for the latest rise in unemployment; in the United Kingdom the equation actually overpredicts the rise in unemployment, given the jump in $W^{g}$ from 3.0 percent in 1978 to 19.1 percent in 1981. Data are not available to project the 1982 unemployment rate for Canada and Japan. The last two columns of the display show forecasts from equations that add lagged real money balances, $\left(M / P_{C}\right)_{t-1}$, as a demand variable. The new regression equation is ${ }^{10}$

10. The money variable is M1 for all countries except the United States, for which M2 proved far more satisfactory. Because of problems of data availability, the money variable is an end-of-year measure, rather than an annual average, while the deflator, $P_{C}$, is an annual average. Wherever possible, I have verified that this timing inconsistency is unimportant for the results shown in the text. 
(6) $U_{t}=\alpha_{0}+\alpha_{1} U_{t-1}+\alpha_{2}$ time $+\alpha_{3} W_{t-1}^{g}+\alpha_{4} \log \left(M / P_{C}\right)_{t-1}$.

In table 5 both $W_{t-1}^{g}$ and $\left(M / P_{C}\right)_{t-1}$ are significant explanatory variables in Europe and the demand variable is significant in the United States also. Furthermore, predictions of 1982 unemployment are markedly better:

1982 unemployment rates

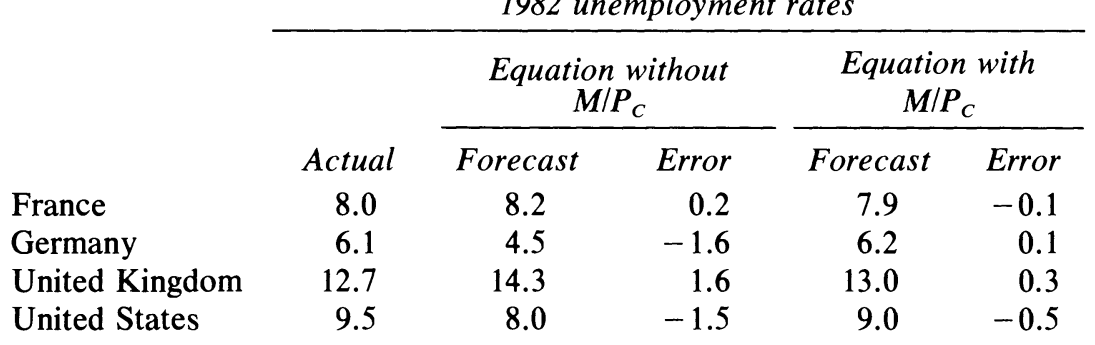

It seems, therefore, that contractionary monetary policies can operate on unemployment independently of their effects on $W^{g}$. In Germany and the United States at least, these independent effects are necessary to explain the sharp recent increases in unemployment. If one turns this proposition around, it can be concluded that a reduction in unemployment may be possible with a demand expansion, even without a reduction in $W^{g}$, though a large wage gap may limit how far demand can reduce unemployment. Obviously a demand expansion may reduce $W^{g}$ also.

The simple disequilibrium models are very clear on this point. Suppose $V^{D}=V^{D}\left(M / P_{C}\right)$ and $V^{S}=V^{S}\left(W / P_{V}\right)$. With $M, W, P_{C}$, and $P_{V}$ fixed, these models determine output as $V=\min \left(V^{D}, V^{S}\right)$. A demand expansion is powerful in raising output as long as $V \leq V^{S}$ (which is probably true in Germany and the United States in 1982), but cannot raise output above $V^{S}$. Without doing formal testing, I would suggest that this view is too restrictive, and that the specification of equation 6 is probably correct: the effects of higher $M / P_{C}$ on $V$, and hence on $U$, are largely independent of whether $V^{D} \gtrless V^{S}$.

The 1970-73 period illustrates this proposition. During this time $W^{g}$ rose sharply while unemployment remained low. A strong demand expansion, reflected in rising real money balances, overcame the contractionary effects of the profit squeeze so that $V^{s}$ fell but actual output remained high. Profits declined despite high output. In effect, firms were probably selling below marginal cost to meet demand. Data for Germany 
illustrate these trends, which prevailed throughout Europe. In 1973 Germany halted the rapid money growth; the following year the unemployment rate doubled, and it virtually doubled again in $1975 .{ }^{11}$ Thus for Germany,

$\begin{array}{lccccc} & 1969 & 1970 & 1971 & 1972 & 1973 \\ \text { Wage gap (percent) } & -0.2 & 1.9 & 2.9 & 5.3 & 8.0 \\ \begin{array}{l}M / P_{C} \text { (percentage deviation from } \\ \text { trend) }\end{array} & 0.8 & 1.0 & 3.2 & 6.2 & -3.5 \\ \text { Unemployment rate (percent) } & 0.9 & 0.7 & 0.9 & 1.1 & 1.3 \\ \text { Profitability (ratio) } & 0.22 & 0.21 & 0.18 & 0.16 & 0.16\end{array}$

\section{DEMAND, SUPPLY, AND INFLATION}

Even if monetary expansion is effective when $W^{g}$ is high, it may have unfortunate inflationary consequences because excess demand, $V^{D}$ $V^{S}$, can be high even if $V^{D}$ itself is relatively low-that is, if high $W^{g}$ has reduced $V^{s}$. Thus $W^{g}$ as a determinant of $V^{s}$ has a role in the Phillips curve. The instability of the Phillips curve in recent years is notorious, and there is a widespread perception that the "inflation threshold," or NAIRU, level of unemployment has risen in the 1970s. Part of this shift can be understood as a consequence of the wage-induced shift in $V^{S}$.

I begin with a standard Phillips curve and add $W^{g}$ as an explanatory variable. Current inflation is explained by distributed lags of inflation, $L p_{C},\left(0.5 p_{C_{t-1}}+0.3 p_{C_{t-2}}+0.2 p_{C_{t-3}}\right)$; import price changes, $L p_{M}$, $\left(0.5 p_{M_{t}}+0.5 p_{M_{t-1}}\right)$; unemployment, $L U,\left(0.5 U_{t}+0.5 U_{t-1}\right)$; and the wage gap, $L W^{g},\left(0.5 W_{t}^{g}+0.5 W_{t-1}^{g}\right)$ :

$$
p_{C}=\alpha_{0}+\alpha_{1} L p_{C}+\alpha_{2} L p_{M}+\alpha_{3} L U+\alpha_{4} L W^{g} .
$$

The results, shown in table 6, generally support the theory. In every country a rise in $W^{g}$ shifts the Phillips curve upward, so that current inflation is raised at each level of apparent slack, as measured by unemployment. The shift is particularly significant in Germany, the United Kingdom, and the United States. The point estimates suggest that the inflationary consequences of a 1.0 percentage point rise in $W^{g}$

11. Unemployment in 1974 was 2.6 percent and in $1975,4.7$ percent.

The $M / P_{C}$ measure for Germany is calculated by regressing the logarithm of $M / P_{C}$ on time for 1960-68 and then taking deviations of actual values from this time trend for 1969-73. 
Table 6. Phillips Curve Equations for Consumer Prices, 1963-81 ${ }^{\text {a }}$

\begin{tabular}{|c|c|c|c|c|c|c|}
\hline \multirow[b]{3}{*}{ Country } & \multicolumn{4}{|c|}{ Independent variable } & & \\
\hline & \multirow{2}{*}{$\begin{array}{l}\text { Lagged } \\
\text { rate of } \\
\text { change } \\
\text { in con- } \\
\text { sumer } \\
\text { prices }\end{array}$} & \multirow{2}{*}{$\begin{array}{l}\text { Lagged } \\
\text { rate of } \\
\text { change } \\
\text { in } \\
\text { import } \\
\text { prices }\end{array}$} & \multirow{2}{*}{$\begin{array}{l}\text { Lagged } \\
\text { unemploy- } \\
\text { ment } \\
\text { rate }\end{array}$} & \multirow[b]{2}{*}{$\begin{array}{c}\text { Lagged } \\
\text { wage gap }\end{array}$} & \multicolumn{2}{|c|}{ Summary statistic } \\
\hline & & & & & $\bar{R}^{2}$ & $\begin{array}{l}\text { Durbin- } \\
\text { Watson }\end{array}$ \\
\hline Canada & $\begin{array}{c}0.39 \\
(1.45)\end{array}$ & $\begin{array}{c}0.38 \\
(3.06)\end{array}$ & $\begin{array}{c}-0.39 \\
(-0.91)\end{array}$ & $\begin{array}{l}18.21 \\
(0.58)\end{array}$ & 0.83 & 1.14 \\
\hline France & $\begin{array}{c}-0.05 \\
(-0.23)\end{array}$ & $\begin{array}{c}0.26 \\
(5.80)\end{array}$ & $\begin{array}{c}1.20 \\
(3.30)\end{array}$ & $\begin{array}{l}14.88 \\
(0.93)\end{array}$ & 0.90 & 1.56 \\
\hline Germany & $\begin{array}{c}-0.17 \\
(-0.93)\end{array}$ & $\begin{array}{c}0.06 \\
(1.76)\end{array}$ & $\begin{array}{c}-1.54 \\
(-7.35)\end{array}$ & $\begin{array}{l}63.58 \\
(6.88)\end{array}$ & 0.88 & 2.16 \\
\hline Japan & $\begin{array}{c}0.07 \\
(0.25)\end{array}$ & $\begin{array}{l}0.15 \\
(2.65)\end{array}$ & $\begin{array}{l}-13.51 \\
(-2.10)\end{array}$ & $\begin{array}{l}50.05 \\
(1.73)\end{array}$ & 0.58 & 2.07 \\
\hline United Kingdom & $\begin{array}{c}0.43 \\
(2.27)\end{array}$ & $\begin{array}{c}0.15 \\
(1.71)\end{array}$ & $\begin{array}{c}-2.01 \\
(-2.54)\end{array}$ & $\begin{array}{l}95.89 \\
(3.95)\end{array}$ & 0.88 & 2.31 \\
\hline United States & $\begin{array}{c}0.85 \\
(5.48)\end{array}$ & $\begin{array}{c}0.17 \\
(5.00)\end{array}$ & $\begin{array}{c}-1.21 \\
(-3.68)\end{array}$ & $\begin{array}{l}36.25 \\
(2.88)\end{array}$ & 0.90 & 1.34 \\
\hline
\end{tabular}

Sources: Author's estimates of text equation 7, with data from sources cited in table 5 .

a. The dependent variable is the current rate of change in the consumer price index. See text for an explanation of the lags. The unit-value index for imports is used to calculate changes in import prices. The numbers in parentheses are $t$-statistics.

are equivalent to a fall in unemployment of 0.5 percentage point in Canada, 0.4 point in Germany, 0.04 point in Japan, 0.5 point in the United Kingdom, and 0.3 point in the United States. These estimates are close to the long-run effects on unemployment of higher $W^{g}$ discussed above.

The inclusion of $W^{g}$ in the Phillips curve equation reduces the importance of lagged inflation in the equations for Germany and Japan. Compare the coefficient on lagged $p_{C}$ in equations with and without $W^{g}$ ( $t$-statistics in parentheses):

\begin{tabular}{|c|c|c|}
\hline & With Wg & Without $W^{g}$ \\
\hline & $-0.17(-0.93)$ & $0.51(1.72)$ \\
\hline & $0.07 \quad(0.25)$ & $0.31(1.25)$ \\
\hline
\end{tabular}

There is no evidence of inertial inflation in these countries once the Phillips curve more adequately measures aggregate supply. In general what appears as inflation inertia may in fact reflect the persistent operation of a variable that has been left out, such as the wage gap. 
One further demonstration of the importance of $W^{g}$ for aggregate supply relies on the well-known factor-price frontier. ${ }^{12}$ Returning to the Cobb-Douglas production function, $V=\left(e^{\lambda t} L\right)^{\alpha} K^{(1-\alpha)}$, I define profitability as $\pi=\left[V-\left(W / P_{V}\right) L\right] / K$, and full-employment efficiency labor as $\tilde{L}^{f}=e^{\lambda t} L^{f}$. Then it is straightforward to show that when $L=L^{D}$ (see equation 2 above), or equivalently, when $\partial V / \partial L=W / P_{V},{ }^{13}$

$$
\log \pi=-[\alpha /(1-\alpha)] W^{g}-\alpha \log \left[K / \tilde{L}^{f}\right]+\text { constant } .
$$

Thus the (log) rate of return to capital is a linear, decreasing function of $W^{g}$ and $(\log )$ capital intensity, $\left(K / \tilde{L}^{f}\right)$. Because $L$ does not always equal $L^{D}$ if firms are demand-constrained, actual profitability may differ from equation 8.

In the regressions in table 7 , I confirm that $W^{g}$ has a strong role in explaining profits, after allowing for a time trend (to capture secular changes in the $K / \tilde{L}^{f}$ variable) and for the direct cyclical effects of unemployment on $\pi$. The estimated equation is

$$
\log \pi_{t}=\alpha_{0}+\alpha_{1} W_{t}^{g}+\alpha_{2} \text { time }+\alpha_{3} U_{t} .
$$

Note that the estimates of $\alpha_{1}$ are negative and always very significant, again with the exception of the United States. For the other countries, profitability can be improved directly by a reduction in $U$ or by a fall in $W^{g}$. Each 1.0 percentage point reduction in $W^{g}$ is associated with a rise in the profit rate of 0.4 percentage point in Canada, 0.3 point in France, 0.2 point in Germany, 0.7 point in Japan, and 0.2 point, both in the United Kingdom and in the United States. A fall in the British wage gap to zero from the 1981 level would raise the rate of return from approximately 4.1 to 8.5 percent. Note also that there is an exogenous downward trend in the rate of return in Canada, Germany, the United Kingdom, and the United States, presumably reflecting the trend increase in $K / \tilde{L}^{f}$.

12. Michael Bruno was among the first to note the importance of the factor-price frontier for the supply developments in the 1970s in "Raw Materials, Profits, and the Productivity Slowdown," Working Paper 660 (National Bureau of Economic Research, 1981). See also Bruno and Sachs, "Input Price Shocks and the Slowdown in Economic Growth."

13. When $\partial V / \partial L=W / P_{V}$, one may write $\pi$ as $[V-(\partial V / \partial L) L] / K$. By Euler's equation, $V=(\partial V / \partial L) L+(\partial V / \partial K) K$, so $\pi$ also equals $(\partial V / \partial K)$. It is then straightforward to calculate $\partial V / \partial K, \partial V / \partial L,(V / L)^{f}$, and $W^{g}=\log \left[\left(W / P_{V}\right) /(V / L)^{f}\right]$. Combining the resulting expressions yields text equation 8 . 
Table 7. Rate of Return on Manufacturing Capital, Selected Periods, 1960-81 ${ }^{\mathrm{a}}$

\begin{tabular}{|c|c|c|c|c|c|}
\hline \multirow[b]{3}{*}{ Country and period } & \multicolumn{3}{|c|}{ Independent variable } & \multirow{2}{*}{\multicolumn{2}{|c|}{ Summary statistic }} \\
\hline & \multirow[b]{2}{*}{$\begin{array}{l}\text { Wage } \\
\text { gap }\end{array}$} & \multirow{2}{*}{$\begin{array}{l}\text { Unem- } \\
\text { ployment } \\
\text { rate }\end{array}$} & \multirow[b]{2}{*}{$\begin{array}{l}\text { Time } \\
\text { trend }\end{array}$} & & \\
\hline & & & & $\bar{R}^{2}$ & $\begin{array}{l}\text { Durbin- } \\
\text { Watson }\end{array}$ \\
\hline Canada (1960-79) & $\begin{array}{c}-3.2 \\
(-4.89)\end{array}$ & $\begin{array}{c}0.00 \\
(0.00)\end{array}$ & $\begin{array}{c}-0.011 \\
(-4.65)\end{array}$ & 0.50 & 1.07 \\
\hline France (1967-79) & $\begin{array}{c}-2.18 \\
(-3.02)\end{array}$ & $\begin{array}{c}-0.24 \\
(-4.88)\end{array}$ & $\begin{array}{c}0.06 \\
(3.36)\end{array}$ & 0.82 & 2.30 \\
\hline Germany (1960-80) & $\begin{array}{c}-1.78 \\
(-3.01)\end{array}$ & $\begin{array}{c}0.00 \\
(0.00)\end{array}$ & $\begin{array}{c}-0.014 \\
(-2.55)\end{array}$ & 0.91 & 1.39 \\
\hline Japan (1965-80) & $\begin{array}{c}-3.51 \\
(-6.02)\end{array}$ & $\begin{array}{c}-0.30 \\
(-3.51)\end{array}$ & $\begin{array}{r}-0.037 \\
(-3.69)\end{array}$ & 0.96 & 1.81 \\
\hline United Kingdom (1960-81) & $\begin{array}{c}-3.79 \\
(-6.70)\end{array}$ & $\begin{array}{c}-0.01 \\
(-0.72)\end{array}$ & $\begin{array}{l}-0.009 \\
(-1.61)\end{array}$ & 0.95 & 1.32 \\
\hline United States (1960-81) & $\begin{array}{c}-1.34 \\
(-1.16)\end{array}$ & $\begin{array}{c}-0.06 \\
(-2.70)\end{array}$ & $\begin{array}{c}-0.013 \\
(-2.57)\end{array}$ & 0.66 & 0.79 \\
\hline
\end{tabular}

Sources: Author's estimates of text equation 9 based on data from sources cited in table 5 . The profitability data are from the national income account statistics of the OECD.

a. The dependent variable is the log ratio of gross operating surplus (profits plus capital-consumption adjustment plus income of self-employed persons) to replacement cost of total capital stock. The numbers in parentheses are $t$ statistics.

\section{Implications of the Real Wage Gap for Demand Management}

It is often incorrectly argued that "classical" unemployment due to a wage gap cannot be treated by Keynesian policies. But the real wage argument does not, in itself, provide a case against expansionary macroeconomic policies. As I noted at some length in my 1979 BPEA paper, demand expansion may be very helpful in fostering recovery, particularly if the demand policies themselves help to reduce the wage gap. Whether they do depends on how wages, prices, and productivity respond to the demand stimulus.

The Great Depression provides a vivid illustration of that proposition. An observer of the early years of the depression could have made a "profit squeeze" analysis of the sort made in the first half of this paper. Sheila Bonnell makes this point in a fascinating recent note in the Economic Record, from which I adapt some data in tables 8 and 9.

In 1934 the first half of this paper might have been written like this:

The major economies of the world have been subjected to a profit squeeze of remarkable proportions during 1929-33. In all major economies, the high productivity growth of the 1920s ended abruptly in 1929, and though Denison 
Table 8. Wages and Productivity during the Great Depression, Selected Periods, 1928-37

Percent

\begin{tabular}{lccccc}
\hline & \multicolumn{2}{c}{ Product wage growth } & & \multicolumn{2}{c}{ Productivity growth } \\
\cline { 2 - 3 } \cline { 5 - 6 } Country & $1928-32$ & $1932-37$ & & $1928-32$ & $1932-37$ \\
\hline Germany & 7.7 & -4.9 & & -2.2 & 3.6 \\
Sweden & 1.9 & 0.4 & & -0.5 & 4.8 \\
United Kingdom & 2.8 & -1.2 & & -0.8 & 1.5 \\
United States & -2.5 & 4.4 & & -4.9 & 3.9 \\
\hline
\end{tabular}

Source: Adapted from Sheila Bonnell, "Real Wages and Employment in the Great Depression," Economic Record, vol. 57 (September 1981), pp. 277-81.

and others have not yet fully accounted for the slowdown, it appears that some of the loss is irretrievable even if a recovery gets under way. Despite the slowdown, real wage growth has remained strong in European economies. In Germany product wages, $W / P_{V}$, grew at 7.7 percent a year in the past four years, even though productivity levels have been falling sharply! In the United Kingdom and Sweden real wage resistance has kept wage growth positive despite high unemployment. Only in the United States have workers accepted negative wage growth in line with productivity developments, though even the productivity fall there has been too steep to keep profit shares constant.

The result of all of this is a remarkable profit squeeze that has sent labor's share from an index of 100 during 1925-29, to 1932 values of 138.0 in Germany, 109.0 in Sweden, 115.9 in the United Kingdom, and 111.1 in the United States. Firms adjusted to this sharp rise in real labor costs by moving up their schedule of demand for labor, with the result that unemployment exceeded 20 percent in Germany, Sweden, and the United States, and over 15 percent in the United Kingdom.

Thus it seems clear that recovery will only come when profit margins have been restored, which means that growth of real wages will have to be severely constrained in Europe for the next several years.

Robert J. Gordon, who might have been the discussant of this work, would have asked, for instance, for underlying trend productivity growth calculations for 1928-32 rather than the actual rates shown in the table. He might also have noted that the profit-squeeze hypothesis, while interesting, simply does not fit the data, pointing out that the United Kingdom, with a larger increase in the share of labor during 1928-32, had a lower unemployment rate than the United States and Sweden. Finally, James Tobin might have observed that none of this precludes faster money growth as a solution to the crisis.

The three main points of the hypothetical discussion-excess product 
Table 9. Labor Share and Unemployment Rate during the Great Depression, Selected Years, 1928-37

\begin{tabular}{lrrrrrrrr}
\hline & \multicolumn{3}{c}{ Labor share (index) } & & \multicolumn{3}{c}{$\begin{array}{c}\text { Unemployment rate } \\
\text { (percent) }\end{array}$} \\
\cline { 2 - 3 } \cline { 7 - 9 } \multicolumn{1}{c}{ Country } & 1928 & 1932 & 1937 & & 1928 & 1932 & 1937 \\
\hline Germany & 92.6 & 138.0 & 90.0 & & $9.3^{\mathrm{a}}$ & 30.1 & 4.6 \\
Sweden & 99.0 & 109.0 & 87.5 & & $10.2^{\mathrm{a}}$ & 23.4 & 10.9 \\
United Kingdom & 100.4 & 115.9 & 101.2 & & 7.5 & 15.6 & 7.8 \\
United States & 101.0 & 111.1 & 114.0 & & 4.4 & 23.6 & 14.3 \\
\hline
\end{tabular}

Source: Same as table 8 .

a. Data for 1929.

wage growth, the difference of cyclical and trend productivity, and the usefulness of expansionary policy-are all correct in the context of 1934 . Germany, Sweden, and the United Kingdom achieved a strong recovery by 1937 , in each case led by reflationary policies. In Germany it was the combination of heavy rearmament and capital controls under the Nazi regime that restored demand. In the United Kingdom the 1931 devaluation was decisive in breaking the fall in prices, and eventually restoring demand and profits. In Sweden a combination of expansionary domestic policies and rising exports to Germany was responsible for the demandled recovery. In all these cases, given rigidities in nominal wages, the demand expansions reduced real wage growth and at the same time allowed a cyclical boost to productivity. The profit share in each case returned to the 1928 level, and with it, the unemployment rate. In the United States neither the profit share nor unemployment was restored to levels that existed before the depression until World War II.

The difference between the 1930s and 1980s in the task facing demand management lies neither in the necessity of restoring profit margins nor in the need for moderation of real wages. The difference lies in the capacity of demand policies to bring about the needed rise in profits, particularly in ways that are compatible with inflation targets. There are three points here that form the basis for the remaining discussion on implications of the real wage gap.

First, part of the mechanism of demand policy is to engineer real wage moderation through higher inflation. While this was feasible in the 1930s, and perhaps is still today in the United States, it provides a dubious basis for policy in most European OECD economies. Demand management can still serve this role, but only if it is combined with an explicit 
understanding with the major wage negotiators that real wage moderation is required.

Second, in the 1930s there were tremendous productivity dividends to be reaped from an expansion. The case for such large dividends is more dubious today.

Third, the "room for maneuver" for policymakers is still somewhat limited. In the beginning of the depression, prices had declined significantly, so that inflationary policies were not only palatable, but desirable. In the United Kingdom there was little discussion about a 10 percent rise in the consumer price index during 1933-37 in view of the 15 percent fall in the previous five years. When the same policies start from a high level of inflation, they can be far less attractive.

Despite these caveats, the data do suggest the possibility of a noninflationary, demand-led recovery in Europe, if real wage growth can be sustained at current low levels through a period of demand expansion. This argument is presented below.

To judge the possible effectiveness of demand policies, one must place the wage gap in an overall macroeconomic framework. As a first step I focus on the interactions among wages, prices, and productivity to examine how a demand expansion would affect $W^{g}$. I then examine the room for maneuver with the assumption of an unchanged wage gap.

\section{WAGE AND PRICE DETERMINATION}

Econometric studies by a number of authors, including those by Gordon, by Branson and Rotemberg, and by me in my 1979 BPEA paper, indicate that nominal wage growth in Europe is so closely linked to consumer price developments that a demand expansion is likely to raise $W^{8}$ rather than reduce it as in the $1930 \mathrm{~s} .{ }^{14}$ The contrary seems to be true in the United States, and perhaps also in Canada. Before turning to some econometric evidence on this point, I present stylized versions of wageprice equations for the United States and the major European economies ("Europe"' in this discussion).

14. See William H. Branson and Julio J. Rotemberg, "International Adjustment with Wage Rigidity," European Economic Review, vol. 13 (May 1980), pp. 309-32; Robert J. Gordon, "Why U.S. Wage and Employment Behaviour Differs from That in Britain and Japan," Economic Journal, vol. 92 (March 1982), pp. 13-44; and Sachs, “Wages, Profits and Macroeconomic Adjustment." 
In the United States nominal wage growth is well described as a function of unemployment and a distributed lag of changes in consumer prices. In Europe the link between changes in wages and consumer prices is virtually instantaneous. Thus for the United States,

$$
w=\alpha_{0}-\alpha_{1} U+\alpha_{2} p_{C}+\left(1-\alpha_{2}\right) p_{C_{t-1}}, \quad \alpha_{2}<1,
$$

and for Europe,

$$
w=\alpha_{0}-\alpha_{1} U+p_{C} .
$$

Value-added prices are well represented in the United States as an almost instantaneous markup over normal unit-labor costs. The markup may vary positively with the cycle..$^{15}$ Value-added prices in Europe, however, do not respond rapidly to, nor on a one-for-one basis with, changes in unit-labor costs. It appears that prices respond strongly to excess demand, $V^{D} / V^{S}$, therefore falling with high unemployment and rising with high wage gaps-that is, low $V^{s}$. The linkage between wage costs and prices is present, via wage effects on $V^{s}$, but in an attenuated form and with a greater lag than in the United States. Illustrative equations for the United States are ${ }^{16}$

$$
p_{V}=w-\left(v^{f}-\ell^{f}\right)-\beta_{0}\left(U-U_{t-1}\right),
$$

and for Europe,

$$
p_{V}=\beta_{1}-\beta_{2} U+\beta_{3} W^{g} .
$$

In both economies the gap between $p_{C}$ and $p_{V}$ is explained by changes in nonwage costs such as those that arise from changes in the terms of trade and indirect taxes. For instance,

$$
p_{C}=p_{V}-\gamma_{0}(t o t),
$$

where (tot) signifies the percentage change in terms of trade. An improvement in the terms of trade (tot $>0$ ) reduces consumer prices relative to value-added prices.

15. See Robert J. Gordon, "The Impact of Aggregate Demand on Prices," BPEA, 3:1975, pp. 613-62.

16. The markup equation for the United States is typically stated in level form, as $P_{V}=m(U) W /(V / L)^{f}$, where $m(U)$ is the variable markup and $W /(V / L)^{f}$ is unit-labor cost. Equation 11a is for rate of change, so price inflation is a function of $w-\left(v^{f}-\ell^{f}\right)$ and the change in $U$. 
The annual change in the wage gap, $\Delta W^{g}$ (or $W_{t}^{g}-W_{t-1}^{g}$ ), is equal to $\left(w-p_{V}\right)-\left(v^{f}-\ell^{f}\right)$. Given the differences in timing in the United States and Europe, demand expansion (a fall in $U$ ), deterioration of the terms of trade, and a slowdown in trend productivity (a reduction in $v^{f}-\ell^{f}$ ), should have very different effects on $W^{g}$ in the two economies. In the model under consideration, the United States would be characterized by

$$
\Delta W^{g}=\beta_{0}\left(U-U_{t-1}\right),
$$

and Europe by

$$
\Delta W^{g}=\alpha_{0}-\alpha_{1} U-\gamma_{0}(\text { tot })-\left(v^{f}-\ell^{f}\right) .
$$

The real wage evolution for the United States is

$$
w-p_{C}=\left(v^{f}-\ell^{f}\right)+\beta_{0}\left(U-U_{t-1}\right)+\gamma_{0}(t o t),
$$

and for Europe is

$$
w-p_{C}=\alpha_{0}-\alpha_{1} U .
$$

Thus in an economy with wages lagging prices, as in the United States, a demand expansion reduces the wage gap; productivity shocks and shocks to the terms of trade affect the real wage directly and do not get built into the wage gap. In economies with wages leading prices, as in Europe, a demand expansion (or, more precisely, a low level of $U$ ) increases the wage gap; productivity shocks and shocks to the terms of trade directly affect $W^{g}$ but do not affect $w-p_{C}$ for a given level of $U$.

Wage and price equations are presented in tables 10 and 11 for the six economies to confirm the differences in behavior just discussed. Table 10 shows estimates of a wage equation like 10a. The effect of inflation on wages in the United States and Canada is partially lagged (with $\alpha_{2}$ significantly below 1.0), while in the other economies the effect is instantaneous (with $\alpha_{2}$ near or above 1.0). The estimates are similar to the results presented in my 1979 BPEA paper.

Table 11 illustrates the differences in price behavior among the six countries. The first row for each economy, showing the estimated equation, is the simple fixed markup relation,

$$
p_{V}=\alpha_{0}+\alpha_{1}\left(w-v^{f}+\ell^{f}\right) .
$$

As expected, $\alpha_{1}$ is estimated as close to 1.0 in the United States and Canada, and less than 1.0 in the other economies. The estimates are not 
Table 10. Nominal Wage Equations for Manufacturing, 1960-81 ${ }^{\text {a }}$

\begin{tabular}{|c|c|c|c|c|}
\hline \multirow[b]{3}{*}{ Country } & \multicolumn{2}{|c|}{ Independent variable } & & \\
\hline & \multirow{2}{*}{$\begin{array}{l}\text { Unemploy- } \\
\text { ment } \\
\text { rate }\end{array}$} & \multirow{2}{*}{$\begin{array}{l}\text { Current } \\
\text { change in } \\
\text { consumer }^{\text {prices }}\end{array}$} & \multicolumn{2}{|c|}{ Summary statistic } \\
\hline & & & $\bar{R}^{2}$ & $\begin{array}{l}\text { Durbin- } \\
\text { Watson }\end{array}$ \\
\hline Canada & $\begin{array}{c}-0.76 \\
(-3.04)\end{array}$ & $\begin{array}{c}0.37 \\
(1.48)\end{array}$ & 0.81 & 0.91 \\
\hline France & $\begin{array}{c}-0.47 \\
(-1.75)\end{array}$ & $\begin{array}{c}0.89 \\
(3.41)\end{array}$ & 0.66 & 2.39 \\
\hline Germany & $\begin{array}{c}-0.62 \\
(-1.76)\end{array}$ & $\begin{array}{c}1.53 \\
(3.05)\end{array}$ & 0.41 & 1.33 \\
\hline Japan & $\begin{array}{c}-9.04 \\
(-5.46)\end{array}$ & $\begin{array}{c}0.88 \\
(6.60)\end{array}$ & 0.79 & 1.26 \\
\hline United Kingdom & $\begin{array}{c}0.04 \\
(0.13)\end{array}$ & $\begin{array}{c}1.22 \\
(7.37)\end{array}$ & 0.83 & 2.37 \\
\hline United States & $\begin{array}{c}-0.45 \\
(-2.14)\end{array}$ & $\begin{array}{c}0.52 \\
(3.56)\end{array}$ & 0.82 & 1.01 \\
\hline
\end{tabular}

Source: Author's estimates of text equation 10a, based on data from sources cited in table 5 .

a. The dependent variable is the rate of change in nominal wages in the manufacturing sector. The numbers in parentheses are $t$-statistics.

b. Current and one-period lagged values were fit with the sum of the coefficients constrained to equal 1.0.

significantly different from 1.0 in the United States, Canada, and the United Kingdom, and are significantly different from 1.0 in France, Germany, and Japan. In the second row for each economy lagged unemployment and the wage gap are added to the equation as explanatory variables,

$$
p_{V_{t}}=\alpha_{0}+\alpha_{1}\left(w-v^{f}+\ell^{f}\right)_{t}+\alpha_{2} W_{t-1}^{g}+\alpha_{3} U_{t-1} .
$$

According to theory, $\alpha_{2}$ should be positive and $\alpha_{3}$ negative, since higher $W^{g}$ raises excess demand and higher $U$ lowers it. Once again, the direct effects of unit-labor costs on prices (measured by $\alpha_{1}$ ) are highest in the United States and Canada and are significantly less than 1.0 in all the other countries. It is probably true that equations $11 \mathrm{a}$ and $11 \mathrm{~b}$ caricature the differences between the United States and Europe, because changes in unit-labor costs are a determinant of price changes in both areas. However, the estimates support the hypothesis that wages feed rapidly into prices in the United States, and more slowly (via $W^{g}$ ) in Europe.

\section{PRODUCTIVITY AND EXPANSION}

The data for the 1930s in tables 8 and 9 show that recovery in Europe brought with it not only deceleration of real wages but also a significant 
Table 11. Price Equations for Manufacturing, 1961-81 ${ }^{\text {a }}$

\begin{tabular}{|c|c|c|c|c|c|}
\hline \multirow[b]{3}{*}{ Country } & \multicolumn{3}{|c|}{ Independent variable } & & \\
\hline & \multirow{2}{*}{$\begin{array}{l}\text { Rate of } \\
\text { change } \\
\text { in nor- } \\
\text { malized } \\
\text { unit-labor } \\
\text { cost }\end{array}$} & \multirow{2}{*}{$\begin{array}{c}\text { Lagged } \\
\text { wage } \\
\text { gap }\end{array}$} & \multirow{2}{*}{$\begin{array}{c}\text { Lagged } \\
\text { unem- } \\
\text { ployment } \\
\text { rate }\end{array}$} & \multicolumn{2}{|c|}{ Summary statistic } \\
\hline & & & & $\bar{R}^{2}$ & $\begin{array}{l}\text { Durbin- } \\
\text { Watson }\end{array}$ \\
\hline \multirow[t]{2}{*}{ Canada ${ }^{b}$} & $\begin{array}{c}0.89 \\
(8.84)\end{array}$ & $\ldots$ & $\ldots$ & 0.81 & 1.24 \\
\hline & $\begin{array}{c}0.86 \\
(9.05)\end{array}$ & $\begin{array}{l}24.40 \\
(0.96)\end{array}$ & $\begin{array}{c}0.49 \\
(1.26)\end{array}$ & 0.85 & 1.47 \\
\hline \multirow[t]{2}{*}{ France } & $\begin{array}{c}0.65 \\
(4.63)\end{array}$ & $\ldots$ & $\ldots$ & 0.51 & 2.16 \\
\hline & $\begin{array}{c}0.40 \\
(3.46)\end{array}$ & $\begin{array}{l}59.05 \\
(3.40)\end{array}$ & $\begin{array}{c}0.69 \\
(1.94)\end{array}$ & 0.77 & 1.70 \\
\hline \multirow[t]{2}{*}{ Germany } & $\begin{array}{c}0.50 \\
(5.70)\end{array}$ & $\ldots$ & $\cdots$ & 0.61 & 1.51 \\
\hline & $\begin{array}{c}0.46 \\
(5.69)\end{array}$ & $\begin{array}{l}18.77 \\
(2.73)\end{array}$ & $\begin{array}{c}-0.40 \\
(-1.57)\end{array}$ & 0.71 & 1.68 \\
\hline \multirow[t]{2}{*}{ Japan $^{\mathrm{b}}$} & $\begin{array}{c}0.66 \\
(6.82)\end{array}$ & $\ldots$ & $\ldots$ & 0.71 & 2.67 \\
\hline & $\begin{array}{c}0.61 \\
(5.23)\end{array}$ & $\begin{array}{c}3.93 \\
(0.33)\end{array}$ & $\begin{array}{c}-2.18 \\
(-0.68)\end{array}$ & 0.68 & 2.76 \\
\hline \multirow[t]{2}{*}{ United Kingdom } & $\begin{array}{c}0.85 \\
(8.31)\end{array}$ & $\ldots$ & $\ldots$ & 0.77 & 2.30 \\
\hline & $\begin{array}{c}0.64 \\
(4.83)\end{array}$ & $\begin{array}{l}67.84 \\
(2.77)\end{array}$ & $\begin{array}{c}-1.41 \\
(-2.09)\end{array}$ & 0.83 & 1.83 \\
\hline \multirow[t]{2}{*}{ United States } & $\begin{array}{c}0.92 \\
(9.17)\end{array}$ & $\cdots$ & $\cdots$ & 0.81 & 1.76 \\
\hline & $\begin{array}{c}0.93 \\
(8.04)\end{array}$ & $\begin{array}{l}17.68 \\
(1.04)\end{array}$ & $\begin{array}{c}-0.51 \\
(-1.78)\end{array}$ & 0.82 & 1.65 \\
\hline
\end{tabular}

Source: Author's estimates of text equations 11c and 11d. Data are from sources cited in table 5 .

a. The dependent variable is the rate of change in the price deflator for manufacturing. Lags are one-period lags. The numbers in parentheses are $t$-statistics.

b. Data on Canada are for 1961-79; data on Japan, 1961-80.

increase in productivity growth that helped restore profitability. Should one now expect that an expansion would also yield a productivity dividend, perhaps one large enough to overcome a rise in $w-p_{C}$ ? To some extent a dividend to the productivity level is allowed for because the wage gap is calculated for a cyclically adjusted value of $V / L$. According to the procedures used for calculating $(V / L)^{f}$ above, actual productivity in 1981 is judged to be 0.3 percent below potential in the United States; 3.2 percent below in France; 3.0 percent below in Germany; and 2.2 percent below in Japan. In the United Kingdom $V / L$ is judged to be more than $(V / L)^{f}$, for reasons described below. 
Have the productivity gains that might follow a fall in $U$ been underestimated? There are two questions here. First, have we underestimated $(V / L)^{f}$ for 1982 , and thus overstated the current wage gap? And second, are there reasons to believe that, whatever the level of $(V / L)^{f}$, future trend productivity growth, $v^{f}-\ell^{f}$, would be higher in a high employment economy? Broadly speaking, the evidence suggests a negative answer for the first question, and a positive one for the second.

Two possible effects must be considered in correcting observed labor productivity for cyclical factors. On the one hand, a demand contraction may lower observed productivity relative to potential if firms carry extensive overhead labor in the downturn. This is the usual effect in U.S. data. On the other hand, if the contraction also involves a profit squeeze, so that the variable costs of the least efficient firms are not covered, the downturn may raise observed productivity. This is the effect predicted by simple production theory. ${ }^{17}$ The low-efficiency, laborintensive firms simply drop out of the data. In contrast to the United States, this effect is predominant in European countries and has been widely noted by several authors. ${ }^{18}$ On these grounds one might expect reductions in average labor productivity in the course of an expansion in Europe as marginal production units are brought back on line.

Productivity developments in the United Kingdom during 1973-82 illustrate both phenomena. In the years after the first oil shock, substantial labor hoarding occurred, with manufacturing productivity growth during 1973-78 rising only 1.8 percent a year, down from 4.3 percent a year during 1960-73. According to OECD, after 1978,

economic conditions worsened significantly faster than in earlier recessions. This was reflected in a marked increase in labour costs in relation to the value of output. . . . The financial pressure on companies caused them to start reducing their workforce before the fall in output became apparent. . . . Changing trade union attitudes, given that many companies risked bankruptcy unless labor

17. With a production function having constant returns to scale, $V=V\left(e^{\lambda} L, K\right)$ and $V / L$ rises as $K / L$ rises. Thus for a given capital stock and a given level of technology, reductions in $L$ raise $V / L$. In the Cobb-Douglas case, $\log (V / L)-\log (V / L)^{f}=-(1-\alpha)$ $\log \left(L / L^{f}\right)$, where $\alpha$ is the share of labor.

18. For the case of small OECD economies see Niels Thygesen, Exchange Rate Experiences and Policies of Small Countries: Some European Examples of the 1970s, Essays in International Finance, 136 (Princeton University, International Finance Section, December 1979), especially pp. 8-12. Thygesen notes on page 9: "If hourly earnings rise faster at home than abroad, production and employment will be reduced until output per manhour has risen to offset the increase in wages" (emphasis mine). 


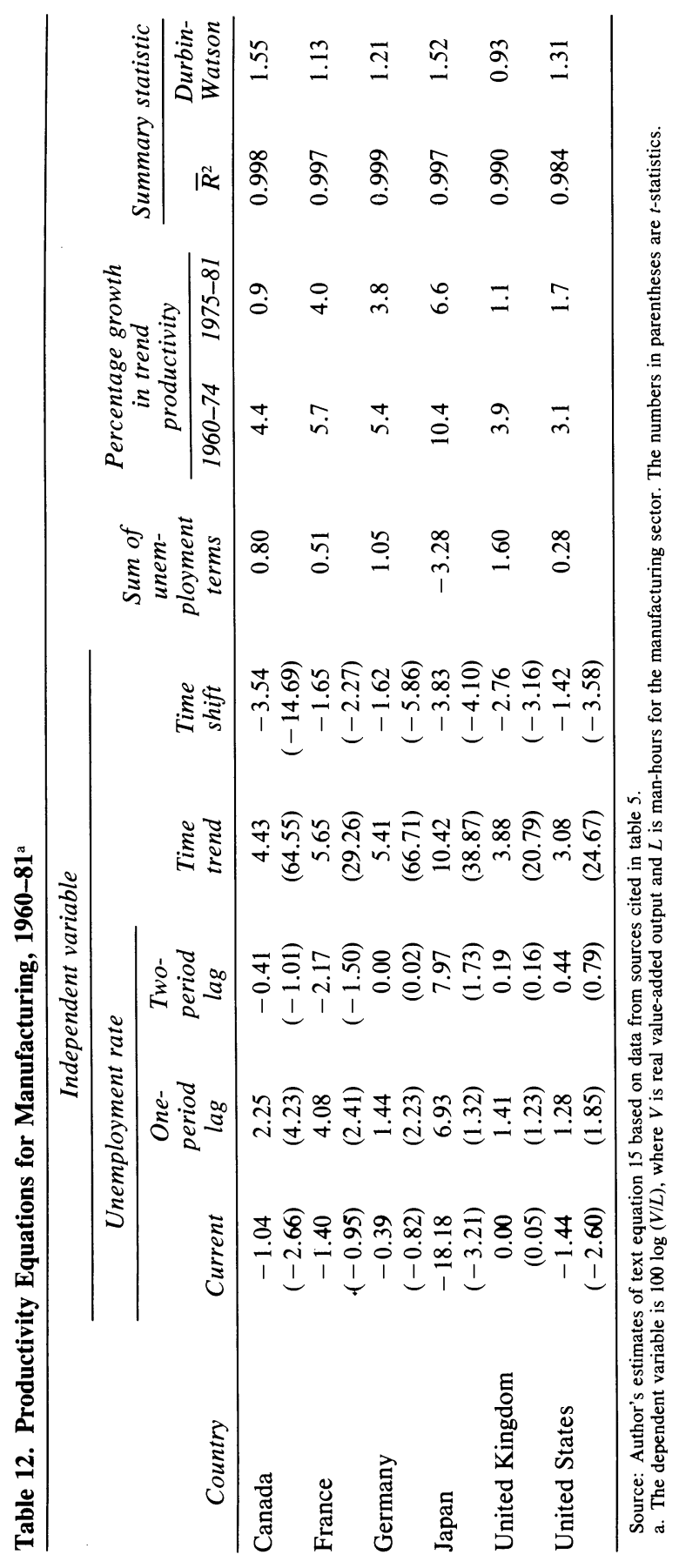


saving economies were made, may help to explain the rapidity with which workforces were reduced without major industrial disruption. ${ }^{19}$

Manufacturing productivity growth in the United Kingdom rose by 3.2 percent a year in 1979-81 during the steep downturn in manufacturing production. It is doubtful that the newly unemployed could be reemployed without a one-shot decline in average productivity on that account.

A measure of these alternative effects can be gleaned from a regression of average labor productivity in manufacturing on aggregate unemployment:

$$
(V / L)_{t}=\alpha_{0}+\alpha_{1} U_{t}+\alpha_{2} U_{t-1}+\alpha_{3} U_{t-2}+\alpha_{4} t i m e+\alpha_{5} t_{75-81} .
$$

The regressions in table 12 suggest that the labor-hoarding phase occurs at the start of a downturn and then is overtaken by the labor-shedding phase in the second year. Note that by including the 1975-81 time-shift variable, I allow for an exogenous decline in trend productivity growth after 1974.

In Europe but not in Japan the overall effect of a sustained rise in unemployment is to raise measured productivity relative to trend. Given the constraints on layoffs in Japan, the productivity effect starts off strongly negative and remains negative on balance after three years. These results suggest that the observed productivity levels in 1979 were probably above potential in the European economies because unemployment had been high there for several years. These levels are probably near or below potential now, given the rapid rise in unemployment recently, which most likely added redundant overhead labor.

Using the estimates of table 12 to measure $(V / L)^{f}$, one can derive a new set of wage gaps based on adjusting observed productivity each year to full employment levels; and these can be compared with the wage gaps developed earlier that were based on trend-line estimates of full-employment productivity. Full employment is defined as the average unemployment rate for $1965-69$, denoted $U^{f}$, and $(V / L)^{f}$ is calculated by replacing the actual $U_{t}$ in equation 15 by $U^{f}$. A wage gap, $W^{*}$, is again created as $\log \left[\left(W / P_{V}\right) /(V / L)^{f}\right]$, with the normalization that $W^{*}$ is zero for 1965-69. The previous measure, $W^{g}$, and new measure, $W^{*}$, are shown in table 13 for three selected years.

19. OECD Economic Surveys: United Kingdom (Paris: OECD, February 1983), p. 13. 
Table 13. Comparison of Alternative Wage-Gap Measures, 1973, 1979, and 1981

\begin{tabular}{|c|c|c|c|c|c|c|}
\hline \multirow[b]{2}{*}{ Country } & \multicolumn{2}{|c|}{1973} & \multicolumn{2}{|c|}{1979} & \multicolumn{2}{|c|}{1981} \\
\hline & $W^{8}$ & $W^{g^{*}}$ & $W^{g}$ & $W^{g^{*}}$ & $W^{g}$ & $W^{g^{*}}$ \\
\hline Canada & -1.4 & -0.4 & -1.4 & 1.4 & n.a. & n.a. \\
\hline France & -0.3 & -0.6 & -0.5 & 3.1 & 1.9 & 4.1 \\
\hline Germany & 8.0 & 7.8 & 8.6 & 14.4 & 12.2 & 17.5 \\
\hline Japan & 9.8 & 6.6 & 21.1 & 16.2 & n.a. & n.a. \\
\hline United Kingdom & 3.1 & 4.9 & 12.8 & 17.3 & 19.3 & 25.3 \\
\hline United States & 3.1 & 5.4 & 6.1 & 6.5 & 8.1 & 8.0 \\
\hline
\end{tabular}

Sources: The $W^{8}$ measure is the same as in table 4 , note a; $W^{*}$ is from author's calculations as described in the text.

n.a. Not available.

The new measure confirms a rising wage gap in recent years in all the economies for which data are available. This measure shows larger gaps than previously estimated in Canada, France, Germany and the United Kingdom, a smaller gap in Japan, and virtually no change in the United States. $W^{g^{*}}$, like $W^{g}$, can track unemployment movements as in table 5 ( $W^{g^{*}}$ and $W^{g}$ are of course highly correlated). It is probably unwise to choose between $W^{g}$ and $W^{g^{*}}$ without more formal econometric estimates of the production technologies in these economies.

The second possible effect of the cycle on productivity is the effect of slack on the productivity trend itself. Several writers have recently contended that slack has affected the trend growth rate, not through the short-run labor-hoarding phenomenon, but through deeper channels including lower capital accumulation, reduced mobility of labor among firms and sectors, and less learning by doing and exploitation of economies of scale. Dickens makes the interesting point that the productivity "lost" in U.S. downturns is not made up during the upturns. The longer is the cyclical downturn, according to this analysis, the lower is the peakto-peak rate of productivity growth. ${ }^{20}$ Similarly, peak-to-peak productivity growth during the Great Depression was generally far below that of the 1920s in European economies. These bits of evidence suggest that a return to higher employment might improve trend productivity growth from 1983 forward. In this case, the restoration of higher employment levels would make room for faster real wage growth in the future, but would do little currently to shift the share of profits in value added.

20. See William T. Dickens, “The Productivity Crisis: Secular or Cyclical?'” Economics Letters, vol. 9, no. 1 (1982), pp. 37-42. 
Thus, unlike in the 1930s, a demand expansion alone is unlikely to reduce the wage gap quickly to zero. In Europe a demand expansion would probably raise $W^{g}$, thereby intensifying the cyclically adjusted profit squeeze. It does not follow that an expansion is therefore unable to lower unemployment or raise profits. Even though $W^{g}$ is high, a demand expansion can still be fully effective. First, if $V^{D}<V^{S}$, a demand expansion can raise output at least to the level of $V^{S}$. Since tight monetary policies rather than a rise in $W^{g}$ seem to explain the recent sharp rise in unemployment in Germany and the United States, there should be scope for expansion in these economies. Second, the previous discussion, particularly of the early 1970s, suggests that demand policies may be able to raise output even beyond $V^{S}$. Firms may be willing, at least for some time, to meet demand at prices below marginal cost (in other words, to produce at $V>V^{S}$ ) in order to maintain market shares and customer relations. The evidence of the early 1970 s does not seem to support the strict disequilibrium view that $V=\min \left(V^{D}, V^{S}\right)$, though this assertion requires careful econometric scrutiny.

Before turning to an assessment of near-term policy alternatives, it is worthwhile summarizing the arguments that have been made on this point:

Real wages remain high relative to full-employment productivity in the manufacturing sectors of the major OECD economies. The wage gap has actually risen since 1979 in France, Germany, the United Kingdom, and the United States.

The large wage gaps, together with the direct effects of extremely tight monetary policies, account for the high OECD unemployment rates. These monetary policies are also a factor in the large wage gaps, at least in the United Kingdom and United States.

Demand expansion and contraction can affect output independently of any effect on $W^{g}$. Specifically, expansionary demand policies can operate even without reducing the wage gap. This is especially true now in the United States and Germany, where the wage gap did not account for the sharp rise in unemployment after 1981.

A large wage gap shifts the Phillips curve upward. A given level of unemployment is more inflationary when $W^{g}$ is high.

A large wage gap shifts the profit rate downward for each level of unemployment. On the other hand, given $W^{g}$, a reduction in unemploy- 
ment raises the rate of return. Thus an expansionary policy can probably raise profitability even if it does not lower $W^{g}$.

A demand expansion would probably raise real wage growth outside the United States, and is thus unlikely to meliorate the wage squeeze (except for the arguments made below).

There is probably no large, one-time productivity dividend waiting to be recaptured with a return to full employment. Because low-efficiency production units have been idled in the past several years, bringing current unused capacity back on line could even involve a one-time drop in average productivity. However, there is probably scope for raising productivity growth over the next several years through a demand expansion.

\section{Policy Choices in the Near Term}

It is beyond the scope of this paper to give detailed prospects for individual economies under various demand management policies. In this concluding section, I make three modest observations. First, in all the major OECD economies, unemployment is now so high that continued reduction in inflation will probably be achieved even without any reduction in $W^{g}$. In other words, unemployment can be reduced now without jeopardizing recent gains in fighting inflation, even if the cyclically adjusted rate of profit is not improved. Second, the fall in oil prices in the past year, which will reduce consumer prices relative to value added prices, should directly raise profitability in the manufacturing sectors of the major OECD economies, just as higher oil prices squeezed profitability in those sectors in 1973 and 1979. Third, there may now be a good opportunity for devising social contracts between governments and trade unions in several European economies under which faster demand expansion is offered in return for continued moderation of real wages.

High real wages should not now be a reason for continued contractionary policies, particularly in Germany. In all the major OECD economies, unemployment at the end of 1982 was so high that continued reductions in inflation are likely even without any reduction in $W^{8}$. To illustrate this proposition, the inflation rate projected from the equations 
in table 6 are shown below for some alternative paths for 1983 import prices, assuming that 1983 unemployment remains at the levels that prevailed at the end of 1982 and that $W^{g}$ remains unchanged from 1982. Given the recent fall in oil prices and the likelihood of U.S. dollar and pound sterling depreciation in the course of 1983, the most likely cases in the display are falling import prices in Germany, stable or slightly rising import prices in the United States, and more marked rises in the United Kingdom-the boldface projections in the display.

\begin{tabular}{lcccc} 
& \multicolumn{4}{c}{ Inflation rate (CPI, year to year) } \\
\cline { 2 - 5 } & \multicolumn{4}{c}{ 1983 forecast of inflation rate } \\
\cline { 2 - 5 } & 5 percent & 5 percent \\
& inflation & in import & in import & in import \\
& rate & prices & prices & prices \\
Germany & 5.3 & $-\mathbf{2 . 2}$ & -2.1 & -1.9 \\
United States & 6.2 & 4.3 & $\mathbf{4 . 8}$ & 5.2 \\
United Kingdom & 8.6 & 5.2 & 5.6 & $\mathbf{6 . 0}$
\end{tabular}

The assumption here that $W^{g}$ will remain unchanged in 1983 may itself be too pessimistic, in which case the inflation projections in each cell for that year are too high. The recent 15 percent fall in the dollar price of petroleum alone should lead to a significant reduction in $W^{g}$ and to a rise in profits. Assuming that the value share of energy inputs in total gross output in manufacturing is now about 10 percent, a 15 percent real reduction in energy input prices should raise $P_{V}$ relative to $P_{C}$ by about 1.5 percent. If $W / P_{C}$ is unaffected by the fall in energy prices, $W / P_{V}$ would also fall by 1.5 percent. In this case, profits would rise approximately 4 to 5 percent (perhaps one-half to one percentage point) according to the estimates in table 7.

Even with this gain, a substantial profit squeeze will remain in Europe, the United States, and Japan. The U.S. situation is probably most easily cured: a reversal of the dollar appreciation of 1980-82 will go far toward reducing $W^{g}$ because nominal wages are unlikely to respond strongly to such a depreciation.

In Europe the problem continues to be more difficult, though several institutional changes on the horizon are promising. After several years of bitter debate in Europe between advocates and opponents of con- 
tinued wage indexation, there have been a number of recent cases in which a compromise on partial indexation was successfully reached. ${ }^{21}$ In 1981 the European Commission adopted guidelines indicating the need for reducing indexation in the face of external shocks or international noncompetitiveness. In 1982 in Belgium, Denmark, France, and Italy various private and public actions were taken to limit the scope of indexation. In Sweden the new socialist government undertook a very large 16 percent devaluation in October 1982, with the apparent understanding of the major trade union federation there that wage bargainers would accept the resulting reduction in real wages. The understanding seems to be that a real wage reduction is a worthwhile price to pay for increased external demand and employment.

It is unfortunate, however, that the major OECD economies have been unable to engineer similar comprehensive arrangements. The trade union movements in those countries reflect skepticism that real wage levels are in any way responsible for the continuing high unemployment. It is particularly hard to identify excess real wages when monetary contraction is clearly the major force behind recent unemployment increases. Meade and Malinvaud have recently responded independently to these doubts by proposing that adjustments in real wages be underwritten by "aggregate demand insurance," in which demand-management policies are in place to prevent real wage reductions from depressing output in the short run. ${ }^{22}$

Although such policies are not now on the public agendas in France, Germany, and the United Kingdom, they deserve careful consideration. Contractionary policies have been shown to achieve moderation of real wages, but at the costs of slower growth and continued high unemployment. Reductions in the wage gap should be easier to engineer on the upswing if trade unions and macroeconomic policymakers properly regard it as a target of policy and a matter for negotiation.

21. For an excellent recent discussion, see Michael Emerson, "The European Stagflation Disease in International Perspective and Some Possible Therapy," paper presented at the Conference of the Centre for European Policy Studies on European Policy Priorities (Brussels, December 1982).

22. See E. Malinvaud, "Wages and Unemployment," Economic Journal, vol. 92 (March 1982), pp. 1-12; and James Meade, "Domestic Stabilisation and the Balance of Payments,' Lloyds Bank Review, no. 143 (January 1982), pp. 1-18. 


\section{APPENDIX}

\section{Wage-Gap Measurement}

THE WAGE GAP is designed to measure the percentage deviation of the actual product wage, $W / P_{V}$, from the wage consistent with full employment of labor. Under the competitive assumption that $\partial V / \partial L=W / P_{V}$, the objective is to compare $W / P_{V}$ with $\partial V / \partial L$ measured at full employment. In a detailed calculation of $W^{g}$ for each country, it would no doubt be best to estimate the production technologies of various sectors econometrically, and to calculate $\partial V / \partial L$ for various possible levels of sectoral employment. The text takes a far simpler approach to illustrate the merits of a wage-gap measure without being burdened by several ancillary problems of econometric estimation. The idea is to assume a Cobb-Douglas technology, for which the marginal product of labor, $\partial V / \partial L$, is a fixed proportion of the average product of labor, $V / L$ (specifically, $\partial V / \partial L=\alpha V / L$, where $\alpha$ is the share of labor). A guess is then made for $(V / L)^{f}$, which is used as an indicator for $(\partial V / \partial L)^{f}$.

This appendix underscores several possible problems with the calculations in the text. These problems are the difficulty of estimating $(V / L)^{f}$; the assumption of proportionality between $V / L$ and $\partial V / \partial L$; the data limitations in measuring $V / L$ and $W / P_{V}$; and the use of manufacturing sector data for the overall economy. These issues are taken up in turn below.

The problems associated with estimating $(V / L)^{f}$ from observed $V / L$ were mentioned in the text. In the first stages of a downturn in a business cycle, typically $V / L<(V / L)^{f}$. If $L$ remains below $L^{f}$ for an extended period, however, it is likely that $V / L>(V / L)^{f}$. In the approach taken in this paper, 1979 is taken as a year in which actual and full-employment productivity are equal. In fact, given the high unemployment rates in Europe for several years up to and including 1979, it is probably true that $V / L>(V / L)^{f}$, and therefore that the wage gap for recent years is underestimated.

Under the Cobb-Douglas assumption, $(V / L)^{f}$ and $(\partial V / \partial L)^{f}$ grow at the same rate. If the production function is not Cobb-Douglas, however, the 
growth of these two variables may diverge. As an example, suppose that $V$ is CES in $K$ and $L$, with Harrod-neutral technological change and the elasticity of substitution, $\sigma$, less than 1.0 :

$$
V^{f}=\left[u\left(e^{\lambda t} L^{f}\right)^{-\rho}+(1-u) K^{-\rho}\right]^{-1 / \rho} \quad \sigma=1 /(1+\rho)<1 .
$$

Then, along a growth path with rising $K^{f} / V^{f},(\partial V / \partial L)^{f}$ will increase more rapidly than $(V / L)^{f}$. The wage-gap measure, which compares $W / P_{V}$ with $(V / L)^{f}$, will overstate the gap between $W / P_{V}$ and $(\partial V / \partial L)^{f}$. Put equivalently, the Cobb-Douglas assumption implies that the normalized labor share of value added should be constant. In fact, with $\sigma<1$ and $(K / V)^{f}$ rising, the normalized labor share should also rise; observed increases in the labor share would not, then, be evidence of excess wages.

This effect does not appear to be of overriding significance, for both empirical and theoretical reasons. Most important, in the rapid deepening of capital of the 1960s the share of labor rose very little, and much less than the increase during 1969-82. Thus during the full-employment growth of the 1960s there is little evidence of a sharp secular rise in the share of labor. On a theoretical level, as long as $\sigma$ is fairly close to 1.0 (say, between 0.6 and 1.0), and technological change is Harrod-neutral, the observed changes in $(K / L)^{f}$ in the 1970s would not explain most of the increase in the share of labor. Nonetheless, capital deepening could explain some of the apparent rise in $W^{g}$, and further econometric work on this point is warranted.

A third problem with $W^{g}$ lies in measurement errors in the valueadded components. In the aggregate national income accounts, the share of employee compensation in value added tends to rise secularly because an increasing proportion of the labor force shifts from self-employed to dependent status. Employee compensation covers dependent employment only. To account for this secular trend a correction is often made for aggregate data by imputing some of self-employed income to employee compensation. The problem is greatly attenuated for the manu facturing sector, in which dependent employment is usually a high and nearly constant proportion of the labor force and small-scale enterprise is often not counted in the measure of value added. Still, it would be useful to look more closely for this possible bias.

The final data problem involves the use of measures for the manufacturing sector to judge the wage-gap problem for an overall economy. This approach reflects nothing more than the problem of data availability, 
for only the manufacturing sector offers good cross-country measures of hours worked and hourly compensation. There are reasons to believe that wage gaps in other sectors would differ from those that I have calculated. A change in exchange rates, for example, can cause important relative price changes within a country between tradable and nontradable goods sectors, so that the same nominal wage developments across sectors can yield very different wage-gap measures. Also, the manufacturing sectors of most of these OECD economies are more highly unionized than other sectors, suggesting that nominal wage developments across sectors within a country might be different, and in particular, that the wage gap in manufacturing might be larger than in the rest of the economy. 


\section{Comments and Discussion}

Robert J. Gordon: One of the most outstanding puzzles in macroeconomics is the enormous increase in unemployment that has taken place in Europe as compared to the United States. In contrast to the 1960s and early 1970s, when the average unemployment rate in major OECD countries (except Italy and Canada) was at roughly half the U.S. rate, by 1983 the unemployment rate in many European countries approached or exceeded that in the United States. In this paper Jeffrey Sachs addresses a central policy question of worldwide concern: can expansionary policy be relied upon to reduce the unemployment rate in Europe, or does the increase in unemployment in Europe have a structural interpretation? Those who support the second interpretation would predict that expansionary policy will be stymied by a steep or vertical aggregate supply curve that translates growth in nominal GNP directly into higher prices rather than higher output.

In asking this question, Sachs extends the analy sis originally suggested by Giersch, by himself at the Brookings Panel in 1979, and by Branson and Rotemberg at the International Seminar in Macroeconomics in 1979. ${ }^{1}$ Those papers were stimulated by the increase in European unemployment relative to that of the United States that had already occurred in the aftermath of the 1973-74 oil shock, and, like Sachs's present paper, they distinguished between overly restrictive policy in Europe and a structural increase in the natural rate of unemployment as

1. See Jeffrey D. Sachs, "Wages, Profits, and Macroeconomic Adjustment: A Comparative Study," BPEA, 2:1979, pp. 269-320; William H. Branson and Julio J. Rotemberg, "International Adjustment with Wage Rigidity," European Economic Review, vol. 13 (May 1980), pp. 309-32; and Herbert Giersch, "Aspects of Growth, Structural Change, and Employment-A Schumpeterian Perspective," Weltwirtschaftliches Archiv, vol. 115 , no. 4 (1979), pp. 629-52. 
alternative interpretations. The leading candidate to explain a structural increase was rigidity in the adjustment of real wage rates to the decline in productivity growth that afflicted most industrial countries after 1973.

In this paper the author's analysis focuses on a new variable called the wage gap, which is simply the actual real product wage divided by the trend in labor productivity. Two other ways of describing the wage gap are as trend unit-labor cost deflated by the value-added deflator, and, perhaps most usefully, as an index of the share of labor compensation in manufacturing value added, adjusted for cyclical movements in labor productivity. The paper consists of a demonstration that the wage gap matters greatly in comparative macroeconomics and offers an explanation of time-series and cross-country movements in unemployment, inflation, and profits.

The paper's basic argument can be summarized in three points: (1) the large wage gaps, together with the direct effects of extremely tight monetary policies, account for the high OECD unemployment rates, which implies that a significant reduction in unemployment requires both a loosening of monetary policy and a reduction in the wage gap; (2) a large wage gap shifts the Phillips curve upward, which suggests that in countries with a large current wage gap, expansionary policy will produce more inflation than in previous periods with a lower wage gap; and (3) a demand expansion is unlikely to meliorate the wage squeeze, that is, lower the wage gap. The paper is ambitious, comprehensive, and stimulating, all the more so because its policy message is profoundly gloomy.

Part of my discussion is already anticipated in the paper by Sachs. In an imaginative and effective aside, Sachs pretends that he is writing in 1934 and shows that the available data at that time could have been misinterpreted as suggesting that the Great Depression was due to excessive real wage growth rather than insufficient aggregate demand. He then suggests what "Gordon, who might have been the discussant of this work, would have asked. ..."' In the lines written out for me, I would have focused on the difference between cyclical and trend productivity and on the lack of cross-country correlation between changes in labor's share and changes in unemployment rates. Indeed, some of my attention below is directed to those issues.

Before I take up those points, however, it is useful to review the predictions of static macroeconomic theory for the connections between 
the wage gap, unemployment, and the business cycle. It is particularly appropriate that William Branson was involved in developing the hypothesis that real wage rigidity is at the heart of Europe's unemployment problem because his graduate textbook, written more than a decade ago, contains a complete analysis of the consequences of nominal and real wage rigidity in a classroom aggregate demand-supply model. Since Sachs's wage gap is the real product wage adjusted for the trend in productivity, the textbook analysis already contains numerous predictions for the behavior of the wage gap in an economy having a zero productivity trend. A review of those predictions follows.

First, the most obvious connection is cyclical. If the price level displays a greater amplitude of procyclical fluctuations than the nominal wage rate, then the real wage, and hence the wage gap, varies countercyclically. A negative correlation between the wage gap and output is thus predicted. If the labor supply curve is vertical and the quantity of labor employed is continuously determined along a downward sloping labor demand curve, then the wage gap is positively correlated with the unemployment rate. Note that this positive correlation occurs without any mention of supply shocks or wage push, nor any implication that the aggregate output supply curve is vertical.

Second, if there is an autonomous upward push on the nominal wage rate, the aggregate supply curve is shifted upward but remains positively sloped. Any temporary loss in output can be "inflated away" by the central bank. The resulting short-run positive correlation between the unemployment rate and wage gap does not imply that expansionary policy is impotent.

Third, if there is an autonomous upward push on real wages, the aggregate supply curve is rotated into a vertical position if workers are able to maintain the new higher real wage with implicit or explicit 100 percent cost-of-living-allowance (COLA) clauses. Now expansionary policy fails to raise output, and an increase in the rate of nominal GNP growth raises the inflation rate in proportion.

Fourth, if an oil shock or other adverse event reduces the level of the marginal product of labor while the real wage remains rigid, the aggregate supply curve also becomes vertical. If the real wage declines but not in full proportion to the drop in labor's marginal product, the aggregate supply curve becomes steeper but not vertical.

This brings me to my first reservation about the paper. To support his 
first major conclusion-that the wage gap helps to explain the secular rise in unemployment since 1973-Sachs points to the positive coefficient on the wage gap in equations explaining unemployment in his table 5. Yet the textbook analysis shows that such a positive correlation has no implications at all for the slope of the aggregate supply curve, and hence for the division between inflation and output growth of an expansionary policy that accelerates nominal GNP growth.

Further, the positive coefficients on the wage gap in his table 5 must mainly reflect cyclical influences, because the wage gap has no predictive power in explaining cross-country differences in the secular rise in unemployment since 1973. This seems obvious in my table 1 below, which contains data on the unemployment rate and wage gap for Sachs's six countries plus Italy, the missing member of Europe's "big four." Leaving aside for the moment the cyclical movement from 1979 to 1981, for Sachs' first conclusion to be validated, those countries experiencing the largest increases in unemployment between the cyclical peak years of 1973 and 1979 should also exhibit the largest increase in their wage gaps. Yet the largest absolute increases in unemployment occurred in France, the United Kingdom, and Germany, in that order, whereas the largest increases in the wage gap occurred in Japan, the United Kingdom, and the United States.

To determine whether this visual impression is correct, I performed some simple correlation tests. For a measure of the change in unemployment, I used both the percentage change and absolute change in unemployment between both 1973 and 1979 and between 1973 and 1981. This was correlated with the absolute change in the wage gap between 1973 and 1979 and between 1973 and 1981, using two estimates of productivity for 1981: first, an extrapolation of 1973-79 trend productivity, and second, actual productivity in that year. The results were uniformly negative, with no correlation yielding a significance level better than 38 percent, in contrast to the usual standard of 5 percent. ${ }^{2}$ The same negative results occurred with new measures of the wage gap, shown in the last three rows of my table 1 and based on the fitted values of productivity regressions, as explained below.

2. The actual test conducted was a regression of a measure of unemployment change on a constant and the change in the wage gap. The highest $t$-ratio on the wage gap was 1.0. There were two regressions for 1979 corresponding to the two measures of unemployment change, and four regressions for 1981, corresponding to the two measures of unemployment change and two measures of the 1981 wage gap. 


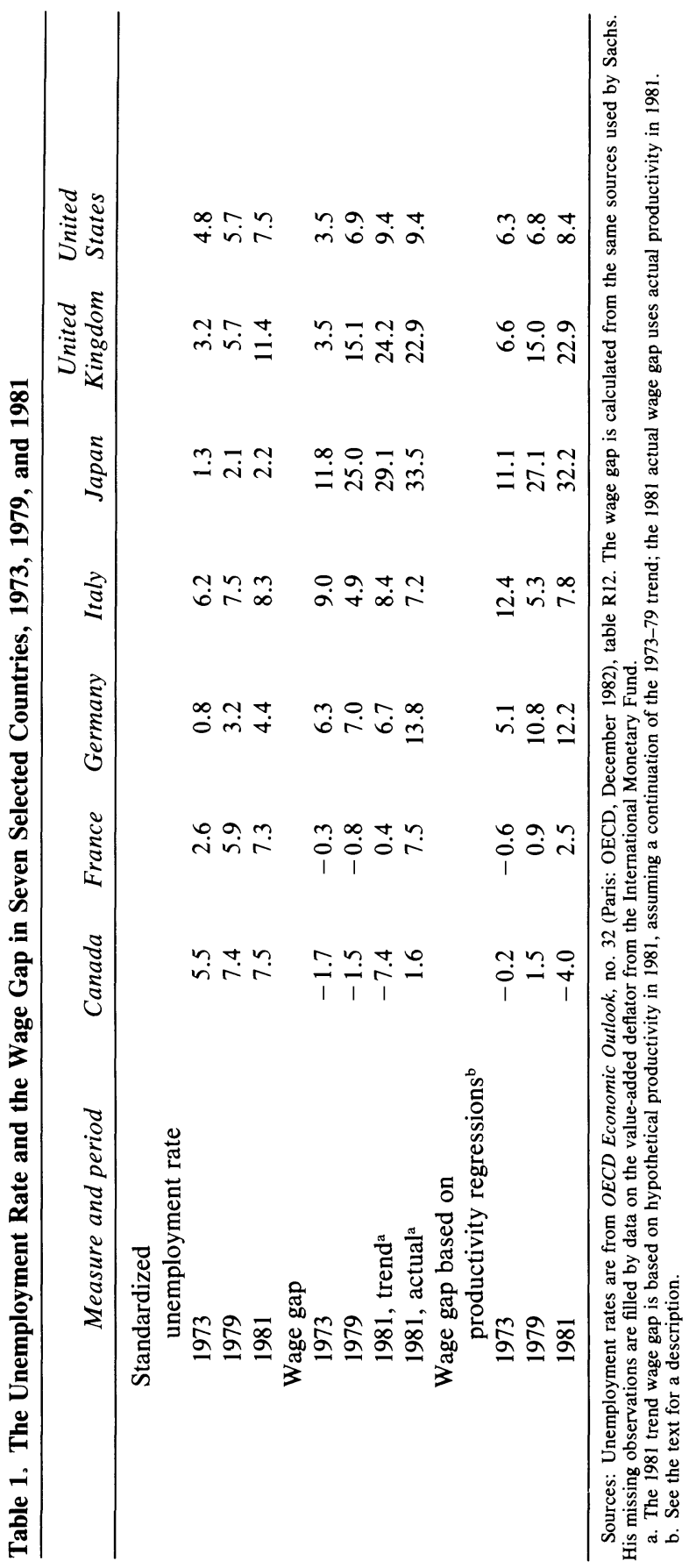


Another fact, not sufficiently emphasized in Sachs's paper, emerges from the data underlying the wage gap calculations. The growth rate of labor productivity in manufacturing slowed in 1973-79 compared to 1960-73 in every one of the seven countries. But real wage rates were not rigid in most countries. As shown by the change in the wage gaps between 1973 and 1979 in table 1 above, the growth rate of real wage rates slowed by as much or more than productivity growth in Canada, France, Germany, and Italy. Only in Japan, the United States, and the United Kingdom did real wage growth slow appreciably less than productivity. Because the behavior of unemployment in the United States appears to pose no mysteries that cannot be explained by demographic changes and aggregate demand fluctuations, and because Japan has not experienced a significant increase in unemployment, the hypothesis of real wage rigidity as a cause of higher unemployment through 1979 appears to be limited to the United Kingdom.

My second reservation concerns Sachs's second conclusion, that the wage gap shifts the Phillips curve upward. This conclusion seems compatible with the emphasis in work by Perry and by me on wage push and supply shocks as a source of upward shifts in the Phillips curve in several OECD countries. ${ }^{3}$ However, Sachs's inflation equations in his table 6 are statistically flawed because they are guaranteed to introduce an upward bias in the coefficient on the wage gap. The easiest way to demonstrate this point is to observe that the wage gap, $W_{t}$, can be rewritten as last period's wage gap, $W_{t-1}^{g}$, plus the current percentage change in the wage rate, $w_{t}$, minus the current change in the value-added deflator, $p_{v_{t}}$, minus trend productivity change, $\gamma$ :

$$
W_{t}^{g}=W_{t-1}^{g}+w_{t}-p_{v_{t}}-\gamma .
$$

Sachs specifies $w_{t}$ in his equation $10 \mathrm{~b}$ for Europe as a linear function of the unemployment rate and the change in consumer prices, $p_{c_{t}}$, the latter having a coefficient of 1.0 , and he finds that the coefficient is 1.0 or above for all countries analyzed except the United States and Canada. Thus we can substitute Sachs's 10b into equation 1 here and obtain

$$
W_{t}^{g}=W_{t-1}^{g}+\alpha_{0}-\alpha_{1} U_{t}+p_{c_{t}}-p_{v_{t}}-\gamma .
$$

3. See George L. Perry, "Determinants of Wage Inflation around the World," BPEA, 2:1975, pp. 403-35; and Robert J. Gordon, "World Inflation and Monetary Accommodation in Eight Countries," BPEA, 2:1977, pp. 409-68. 
In his table 6 Sachs regresses the current change in the consumer price index, $p_{c_{t}}$, on its own lagged values, an average of current and lagged import price changes, an average of the current and lagged unemployment rate, and an average of the current and lagged wage gap. Since the current wage gap as defined in my equation 2 depends on the current value of $p_{c_{t}}$ with a coefficient of 1.0 , table 6 effectively regresses $p_{c_{t}}$ on its own current value. Thus the wage gap variable (which contains $p_{c_{t}}$ ) is positively correlated with the error term in the $p_{c_{t}}$ equations of that table, and thus all the wage-gap coefficients in the table are biased upward.

The section of Sachs's paper that is most novel and interesting to me is the analysis supporting the final conclusion, that Europe differs from the United States not only in the character of its wage-adjustment process, but also in the nature of productivity fluctuations during the business cycle. In the United States one is accustomed to the idea that labor is hoarded in cyclical downturns, so that an expansion of aggregate demand brings with it growth in productivity that is above trend. In Europe, however, Sachs asserts that the overall effect of a sustained rise in unemployment is to raise measured productivity relative to trend. Sachs implies that a demand expansion that reduces unemployment will thus cause productivity growth to decline. By the data of table 1 above, this suggests that not just the 1981 trend measure of the wage gap understates the true gap, but even the 1981 actual may imply an understatement. If productivity growth were to decline further below the 1973-79 trend than what already occurred in 1979-81, and if real wage growth occurs at anything like the recent rates in Europe, the implied wage gaps for a future year like 1985 would be enormous.

Sachs provides table 12 to support the proposition that cyclical productivity behavior differs in Europe compared to the United States. His table shows that, except for Japan, a sustained increase in unemployment raises the level of manufacturing productivity, in the sense that the sum of coefficients on current and lagged unemployment is positive in every country but Japan. There are two problems with the specification that Sachs uses in table 12. First, the dependent variable refers to the manufacturing sector while the right-hand variables for unemployment refer to the entire economy (this is also a problem in tables 5 and 6). Second, there is a secular trend in the unemployment rate series for several countries that may be accounted for by factors other than the wage gap, for example, a demographic shift in the United 
States. Thus I prefer to estimate the cyclical response of labor productivity using the specification developed in my 1979 BPEA paper, with the ratio of hours to trend output, $H / Q^{*}$, related to the ratio of actual to trend output, $Q / Q^{*}: 4$

$$
\frac{H}{Q^{*}}=\left(\frac{Q}{Q^{*}}\right)^{\beta} A e^{-g t} .
$$

If the parameter $\beta$ is 1.0 , a permanent increase in $Q / Q^{*}$ has no effect on actual labor productivity, whereas a lower value of $\beta$ means a permanent productivity gain, and vice versa. In all other respects my attempt to estimate equation 3 duplicates the choices made in Sachs's table 12 (regarding sample period, definition of trend variables, and the choice of a current and two lagged values for the output ratio, $Q / Q^{*}$ ).

The results of this investigation yield different conclusions from those in Sachs's table 12. The first column in the display below shows the estimated sum of the coefficients on the current and two lagged values of the output ratio, $Q / Q^{*}$. To develop the second column, I ran a simulation of the estimated version of my equation 3 for 1982-85 and compared two time paths for $Q / Q^{*}$. In the first the output ratio remains at its 1981 value. In the second the output ratio is raised by expansionary policy by 2.5 percent in 1982 and then by 5.0 percent in $1983-85$ over the 1981 value for each country. A positive number in the second column shows the percentage increase in the level of productivity in 1985 created by the demand expansion; a negative number, the percentage decline in 1985 productivity.

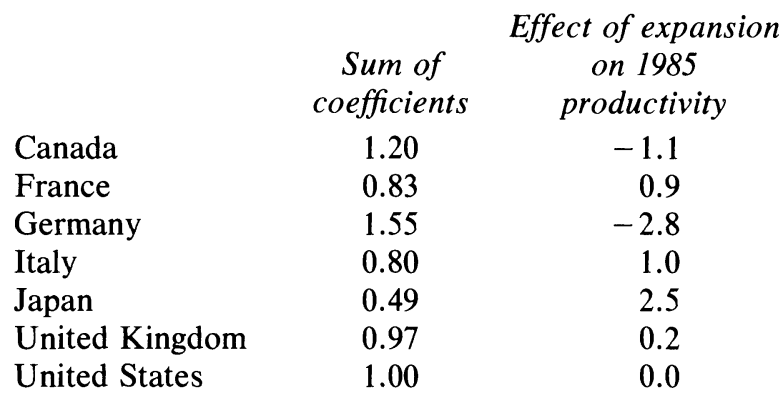

4. See Robert J. Gordon, "The 'End-of-Expansion' Phenomenon in Short-Run Productivity Behavior,' $B P E A, 2 ; 1979$, pp. 447-61. Equation 3 here is also equation 3 in that paper. 
My conclusion is thus that the countercyclical productivity phenomenon emphasized by Sachs on the basis of the results in his table 12 is validated here only for Canada and Germany. There is no marked dichotomy between the United States and Europe. In fact, behavior in France, Italy, and the United Kingdom seems quite similar to that in the United States. ${ }^{5}$ The last three rows of my table 1 above show new values for the wage gap obtained from the fitted values of my productivity regressions when $Q / Q^{*}$ is set equal to 1.0 in each year. These adjusted wage-gap measures differ little from the unadjusted trend measures except in the case of Germany.

A final overall comment on the Sachs paper is that it exaggerates differences in behavior between Europe and the United States. While a detailed evaluation of the wage and price regressions is beyond the scope of these comments, other work done by myself and my student George Kahn indicates that differences in wage and price behavior among Sachs's six countries are a matter of degree, not a matter of kind.$^{6} \mathrm{~A}$ dilemma posed by this type of comparative macroeconomic research is that unusual behavior seems to occur in individual countries rather than a pattern common to a whole set of countries. For instance, in my table 1, Japan is peculiar because of the huge increase in its wage gap without any marked increase in unemployment, while France at the opposite extreme has suffered the greatest increase in unemployment with no important changes in its wage gap. Similarly, Germany seems to be an outlier in the countercyclical nature of its productivity response. The anomalies would multiply if other countries experiencing relatively low increases in unemployment (Austria and Sweden, for instance) were added to the sample. These doubts about the general applicability of the relations developed in the Sachs paper suggest that many fascinating empirical puzzles await resolution by those who are concerned with these central problems in comparative macroeconomics.

5. These results for the United States differ from my 1979 paper in yielding a sum of coefficients of 1.0 rather than 0.8 . Since the two sets of results differ in the sector of the economy covered, they indicate that a permanent increase in $Q / Q^{*}$ in the manufacturing sector does not provide the same permanent productivity bonus as occurs in the private business sector.

6. See Robert J. Gordon, "The Wage and Price Adjustment Process in Six Large OECD Countries," paper presented at the Wingspread Conference on the Evolving International Financial System, Wingspread, Wisconsin, July 1982; and George A. Kahn, "Nominal and Real Wage Stickiness in Six OECD Countries: A Comparative Macroeconometric Analysis" (Ph.D. dissertation, Northwestern University, June 1983). 
Jeffrey D. Sachs: Gordon rejects major elements of my arguments on the basis of three assertions: (1) that the "wage gap" does not explain cross-country differences in unemployment behavior; (2) that the wage gap may not explain Phillips curves shifts as I claim, because the statistical evidence that I present is biased; and (3) that an argument in my paper concerning cyclical productivity behavior is wrong. He also stresses that a large wage gap does not imply a vertical supply schedule, a point on which I concur and to which I devote several pages of text. Gordon's observations are helpful in indicating several areas in which my discussion needs elaboration, but on close scrutiny none of his points presents a major problem for the theses of the paper.

Gordon does not dispute the sharp rise since 1969 in the normalized share of labor throughout the major OECD economies except Canada. Even using his preferred productivity equations, to which I return below, there are important positive wage gaps for all countries except Canada in 1981 (and the modest wage gap for France grows significantly between 1981 and 1982 according to my table 4). The dispute is about the importance of that finding, not whether there has been a shift in labor's share.

My table 5 presents evidence that changes in the wage gap in several countries help to track unemployment in the past two decades. Gordon does not question this evidence, but points out that "such a positive correlation has no implications at all for the slope of the aggregate supply curve," which is of course true, but not germane to the issue of table 5 . The point there is to suggest that real wage moderation is necessary; Gordon's point is that demand expansion may bring it about. This is also the point of my example of the Great Depression. ${ }^{1}$

Gordon's challenge to the argument that real wages are too high rests on cross-country evidence. He compares for seven countries the change in unemployment between 1973 and 1979 (and 1981) with a change in his wage-gap measure for the same period, and finds little cross-country

1. Gordon misconstrues this example by saying that I include it to show that available data at that time could have been misinterpreted to suggest that the Great Depression was due to excessive real wage growth rather than to insufficient aggregate demand. Gordon sets up a false dichotomy here. Both the wage and demand factors were present. Demand deflation raised real wages, and moderation of real wages was necessary for recovery. The moderation was brought about by demand expansion. 
correlation. For example, in his table Japan shows a large wage gap but a small rise in unemployment, while France has a small wage gap and a large rise. There are three explanations for this observation. First, even though unemployment is a function of $W^{g}$ in most economies, it is not the same function everywhere, as Gordon implicitly assumes in his test. Second, there are important lags in the relation between $W^{g}$ and $U$, and hence $U_{t-1}$ is present in my regressions (see my table 5). Third, $W^{g}$ is only one of several variables that may cause unemployment to change. ${ }^{2}$

The first point is probably most important. The text shows that $\log \left(L^{f / L}\right)$ is a positive function of $W^{g}$. However, $\log \left(L^{f} / L\right)$ does not equal the unemployment rate if the labor force changes over the cycle. Let $L^{s}$ be the labor force, with $L^{f}$ the labor input at full employment, and suppose that discouraged-worker effects make $L^{s}=L^{f}\left(L / L^{f}\right)^{b}, 0<b<1 .^{3}$ Define $U$ as $\log \left(L^{s / L}\right)$ and suppose that $\log \left(L / L^{f}\right)=-a W^{g}$, where $a$ is the same across countries. Then $U=a(1-b) W^{g}$. A country with an important discouraged-worker effect will show a small coefficient on $W^{g}$ in the $U$ equation. Japan is a case in point. It is well known that Japanese women who lose their jobs frequently move directly out of the labor force from employment, without ever being counted as unemployed; thus Japan shows very procyclical participation rates. Even if a rise in $W^{g}$ has the same effect on man-hours in Japan as elsewhere, its effect on unemployment will seem far smaller. ${ }^{4}$ Similar effects can be seen in countries like Switzerland, in which job losers are often foreign "guest workers" who return to their country of origin upon job loss. There are several other reasons why the coefficient linking $W^{g}$ to $U$ may differ across countries, including differences in technology, adjustment of labor input through

2. With regard to the second and third points, consider the case of Germany. In 1973, Germany already had a large $W^{8}$, but still a low $U$, in part because of a strong money expansion, as described in the text. Between 1973 and $1979 U$ rose strongly, but $W^{8}$ hardly changed-it remained high throughout the interval. Gordon's simple test would reject a link between $U$ and $W^{g}$. The regressions in table 5 indicate a strong link, but not an instantaneous or exclusive link.

3. With an added-worker effect predominant, $b<0$ would result. The same general theme, that the coefficient on $W^{8}$ in the $U$ equation is sensitive to $b$, would of course still apply.

4. For a recent discussion of Japanese unemployment measures that examines the issue of cyclical participation rates of women, see K. Hamada and Y. Kurosaka, "The Relationship between Production and Unemployment in Japan: Okun's Law in Comparative Perspective," paper presented at the International Seminar on Macroeconomics, Maison des Sciences de L'Homme, Paris, June 1983. 
Table 1. The Slowdown in Growth of Man-hours and Increases in Wage Gaps, 1960-81 ${ }^{\text {a }}$

\begin{tabular}{lcccc}
\hline & \multicolumn{3}{c}{$\begin{array}{c}\text { Growth of man-hours in manufacturing } \\
\text { (annual rates) }\end{array}$} & $\begin{array}{c}\text { Change in } \\
\text { the wage } \\
\text { gap }\end{array}$ \\
\cline { 2 - 4 } Country & $\begin{array}{c}\text { 1960-70 } \\
\text { (percent) }\end{array}$ & $\begin{array}{c}1970-81 \\
\text { (percent) }\end{array}$ & $\begin{array}{c}\text { Slowdown } \\
\text { (percentage } \\
\text { points) }\end{array}$ & $\begin{array}{c}\text { (percentage } \\
\text { points) }\end{array}$ \\
\hline Canada & 1.7 & 0.9 & 0.8 & $-0.6^{\mathrm{b}}$ \\
France & 0.8 & -1.4 & 2.2 & 1.6 \\
Germany & 0.2 & -2.8 & 3.0 & 9.9 \\
Japan & 2.7 & -0.3 & 3.0 & $16.1^{\mathrm{c}}$ \\
United Kingdom & -0.8 & -4.0 & 3.2 & 9.6 \\
United States & 1.4 & 0.4 & 1.0 & 2.4 \\
\hline
\end{tabular}

Source: Author's calculations, based on data from U.S. Department of Labor, Bureau of Labor Statistics, Office of Productivity and Technology, "Underlying Data from Indexes of Output per Hour: Hourly Compensation, and Unit Labor Costs in Manufacturing, Eleven Countries, 1950-81" (BLS, 1982).

a. The change in the wage gap is defined as the average $W^{8}$ for the $1971-81$ period (denoted $W_{71-81}^{g}$ ), minus the average for the 1960-70 period (denoted $W_{60-70}^{\mathrm{g}}$ ). Note that for Japan and Canada the latter period is shortened because recent data are not available.

b. For Canada the change in $W^{8}$ is $W_{71-79}^{8}-W_{60-70}^{g}$

c. For Japan the change in $W^{g}$ is $W_{71-80}^{g}-W_{60-70}^{g}$.

work-week adjustments versus adjustments through layoffs or through early retirement, and so on.

Since the behavior of the labor force varies so widely across countries, a better cross-country test should rely on measures of labor input rather than on comparisons of unemployment. My table 1 above shows a comparison like the one Gordon made, but I have replaced unemployment by growth in man-hours and used decade rates of change, rather than year-over-year measures, to reduce the problem of lags. The evidence for man-hours strongly supports the wage-gap view. Countries with small wage gaps-Canada, France, and the United States-have had much smaller declines in the growth of man-hours in manufacturing than have the countries with large wage gaps-Germany, Japan, and the United Kingdom.

Gordon's second point challenges the role of $W^{g}$ in the Phillips curve equation by pointing out that there may be simultaneous-equations bias on the $W^{g}$ coefficient. This point is overstated. Consider Gordon's equation 2 , which he uses to make the point. Inflation enters only as the difference between $p_{c}$ and $p_{v}$. The bias exists not for pure inflation shocks, but only to the extent that there are variables left out of the price equation that affect $p_{c}-p_{v}$. The main factor affecting this term has 
probably been the external supply shocks, which do appear in the equation through the variable for import prices. In any event, when my equation 7 is recalculated using lagged $W^{g}$ (rather than $0.5 W_{t}^{g}+0.5_{t-1}^{g}$ ), the wage gap is always positive and is significant in three of six cases. ${ }^{5}$ Also, in my table 11 lagged $W^{z}$ is used in the $p_{v}$ equation. Again, the coefficient is always positive and is significant half the time.

Gordon's final point is a critique of my productivity equations. These equations indicate that observed labor productivity may overstate fullemployment labor productivity in economies with a persistently high level of unemployment. Before turning to the substance of the argument I should first indicate that Gordon and I have little important difference in results, with the exception of France. Gordon finds, after all, that (1) there is no large productivity dividend to be recaptured by a return to full employment in Canada, Germany, the United Kingdom, and the United States; (2) the large dividends occur only in Japan (which I also found) and France (where the results conflict); and (3) the wage gaps calculated on Gordon's basis remain large.

Gordon correctly argues that my productivity equation 15 , which regresses $V / L$ on $U$, can be improved by regressing $L$ on $V$. I cannot comment in detail on Gordon's own calculations on this basis, for his results arrived without the supporting equations or details. However, when I follow his lead, and regress

$$
\begin{aligned}
\log \left(L_{t}\right)= & \alpha_{0}+\alpha_{1} \text { time }+\alpha_{2} T_{74-81}+\alpha_{3} \log \left(V_{t}\right) \\
& +\alpha_{4} \log \left(V_{t-1}\right)+\alpha_{5} \log \left(V_{t-2}\right),
\end{aligned}
$$

I find that $\hat{\alpha}_{3}+\hat{\alpha}_{4}+\hat{\alpha}_{5}$ is greater than 1.0 for Canada, Germany, and the United Kingdom (supporting my earlier conclusions), near 1.0 in the United States (as before) and in France (contrary to my equation in the text), and much less than 1.0 in Japan. ${ }^{6}$ Thus a productivity dividend from a return to full employment seems likely only in the United States

5. The coefficients (with $t$-statistics in parentheses) on $W^{g}$ are as follows: Canada, 24.5 (1.22); France, 14.5 (1.16); Germany, 32.8 (2.62); Japan, 33.3 (1.36); the United Kingdom, 82.7 (4.00); and the United States, 26.3 (1.90). The coefficient for the United States is significant at $p=0.10$, and the coefficients for Germany and the United Kingdom at $p=$ 0.05 .

6. Thus my qualitative results agree with those of Gordon for all countries considered except the United Kingdom. I do not know the source of this discrepancy. I find the following values of $\hat{\alpha}_{3}+\hat{\alpha}_{4}+\hat{\alpha}_{5}$ : Canada, 1.22; France, 0.93; Germany, 1.53; Japan, 0.56; the United Kingdom, 1.35; and the United States, 0.93 . 
and France, where the effect will be small, and in Japan, where the effect is significant. And as Gordon's results also show, these gains are in any event too small to eliminate the wage gap that we have both calculated.

\section{General Discussion}

James Duesenberry pointed out that one important implication of the Sachs's paper was the existence of a very strong feedback effect of price changes on wages. Workers appear to be intransigent in their demands for real wage growth, so the effect of price inflation is to raise nominal wages immediately. Duesenberry urged Sachs to explain this result in terms of some simple model of price setting and wage determination.

Laurence Weiss stressed that such a model would have to distinguish between centralized European and decentralized U.S. wage bargaining institutions. Given the institutional framework, he wondered what goals should be attributed to European workers and firms and what theoretical model could explain the apparent responsiveness of output to expansionary demand policy in the absence of movements on real wages. Sachs responded that unions until recently had been attempting to secure constantly growing real wages. This is naturally increasingly hard to accomplish when unemployment rises sharply, as unions have come to recognize. The price-setting behavior of firms appears to be determined within a very long-term framework, with customer relations of paramount importance. In the short run, demand expansion can increase production and alter marginal costs without affecting real wages.

Martin Neil Baily argued that it was implausible to believe in the existence of structurally different wage determination and business cycle models for the United States and Europe. The fact that the equations Sachs estimated showed fundamentally different coefficients for the different economies raised doubts about the reliability of the equations. Sachs responded that, as Weiss had noted, the degree of unionization and the synchronization of bargaining in Europe were quite different from those in the United States. This leads to a difference in timing of many business-cycle phenomena, but not necessarily to a difference in underlying forces governing the economies. There is, for example, a faster passing-through of price changes into wages in Europe but not a 
fundamental difference in long-run behavior. Nonetheless, these timing differences are important for short-term policymaking, and they have caused different economies to respond differently to similar shocks. In several European economies, and in particular in the United Kingdom, real wages are considerably above their full-employment level. Baily also was skeptical that the productivity response to cyclical unemployment could differ across countries as much as estimates by Sachs implied.

Duesenberry argued that the paper should have dealt more thoroughly with the role of international trade in wage determination. Several of the countries considered have very open economies so that the terms of trade could be expected to have important effects on real wage rates. C. Fred Bergsten pointed out a clear correlation between jumps in the wage gap and fluctuations in a country's exchange rate. For example, a major jump in the gap occurred in 1978 for Germany and Japan, two countries whose currencies were overvalued in that year. Similarly, from 1978 to 1982 big jumps occurred in the wage gap in the United Kingdom, the United States, and to some extent France, countries whose currencies became overvalued in that period.

William Fellner commented on the relation between Keynes's policy prescriptions and those of Minister of Economics Otto Lambsdorff for Germany. At the time Keynes wrote the General Theory he saw no contradiction between his conclusion that the real wage was too high and his call for expansionary policies. During the previous years there had been steep deflation of prices, and expansionist policies were not likely to cause inflationary instability. Today, Lambsdorff's views are shaped by the fact that prices have been rising in recent years so that expansionist policies could cause sharp inflationary pressures. 